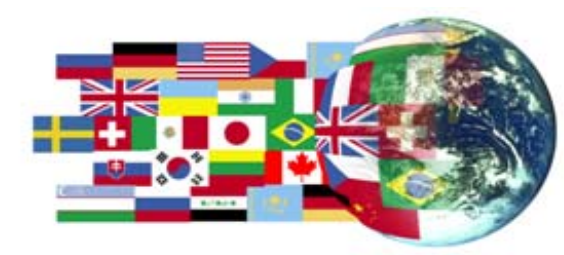

PNNL - 17521

Pacific Northwest Center for

Global Security

\author{
A PNWCGS Publication
}

\title{
Broadening Industry Governance to Include Nonproliferation
}

November 11, 2008

Authors:

G Hund

A Seward

Pacific Northwest

National Laboratory

Operated by Battelle for the

U.S. Department of Energy 


\title{
Disclaimer
}

This report was prepared as an account of work sponsored by an agency of the United States Government. Neither the United States Government nor any agency thereof, nor Battelle Memorial Institute, nor any of their employees, makes any warranty, express or implied, or assumes any legal liability or responsibility for the accuracy, completeness, or usefulness of any information, apparatus, product, or process disclosed, or represents that its use would not infringe privately owned rights. Reference herein to any specific commercial product, process, or service by trade name, trademark, manufacturer, or otherwise does not necessarily constitute or imply its endorsement, recommendation, or favoring by the United States Government or any agency thereof, or Battelle Memorial Institute. The views and opinions of authors expressed herein do not necessarily state or reflect those of the United States Government or any agency thereof.

\author{
PACIFIC NORTHWEST NATIONAL LABORATORY \\ operated by \\ BATTELLE \\ for the \\ UNITED STATES DEPARTMENT OF ENERGY \\ under Contract DE-AC05-76RL01830
}




\section{Acknowledgements:}

The authors wish to thank Frederic Morris and Carol Kessler for their thoughtful review of this paper. 


\section{TABLE OF CONTENTS}

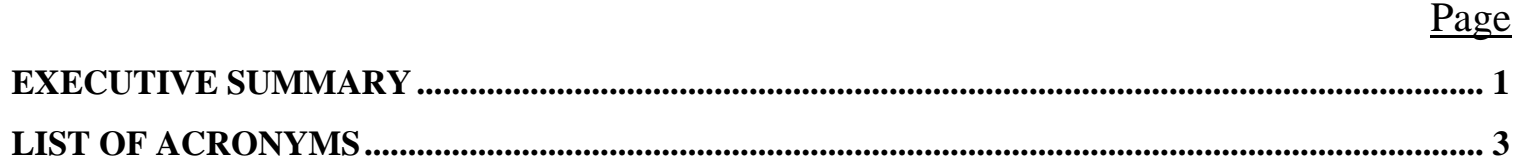

1. What May Prompt Industry to Adopt an Industry Governance / Self-Regulation

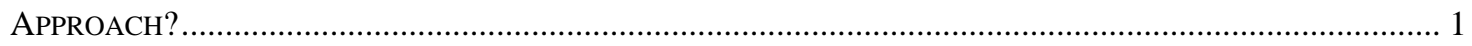

1.1 Concern about Ripple Effect From one Company’s Misdeed …....................................................

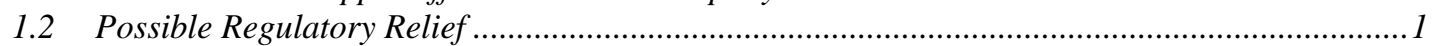

1.3 Possible Improved Relations with Regulators .............................................................................

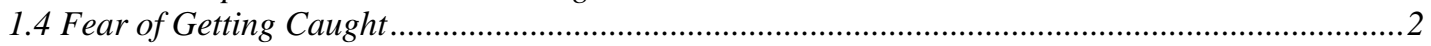

1.5 Interest by Corporate Boards to Adopt Governance Standard Covering Nonproliferation .............2

1.6 Increased Market Value from Adopting an Industry Governance / Self Regulation Approach ........3

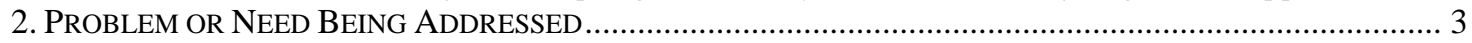

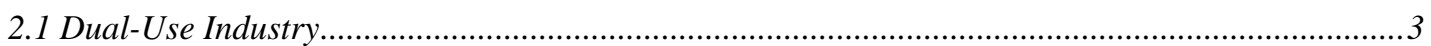

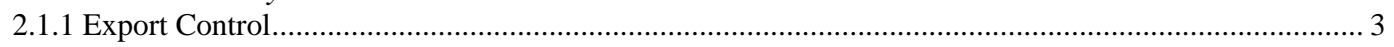

Inadequate verification of End-user (“Catch-All” Controls don't always work) ………............................ 3

Insufficient information exchange by industry on suspicious inquiries or suspected front companies ........ 5

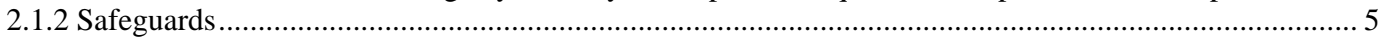

Reporting of information that could help inform IAEA in its evaluation of the completeness of a recipient

state's declarations ........................................................................................................................ 5

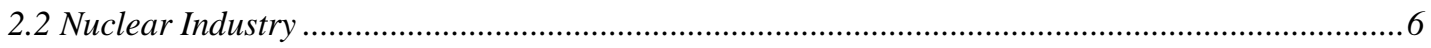

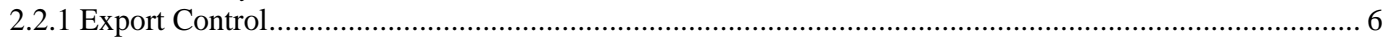

Need to thoroughly review emerging nuclear states' and associated utilities' preparedness to accept

nuclear power components, build a reactor, and/or operate a reactor that they have requested ..................... 6

Insufficient information exchange on suspicious inquiries or suspected front companies ............................. 6

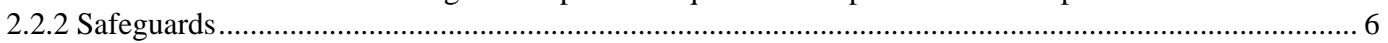
Reporting of information that could help inform IAEA in its evaluation of the completeness of a recipient

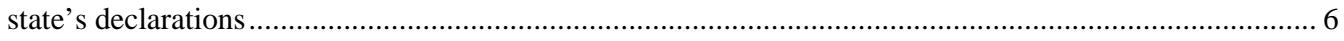

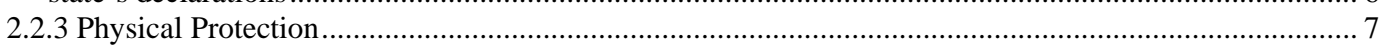

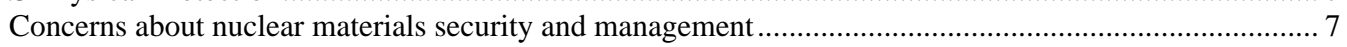

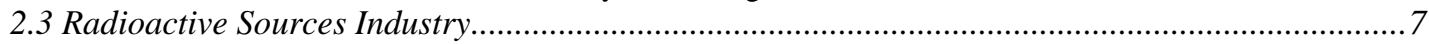

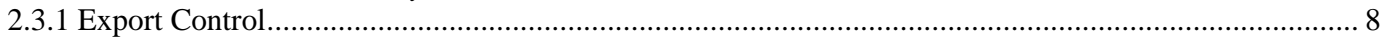

Insufficient information exchange on suspicious inquiries or suspected front companies............................ 8

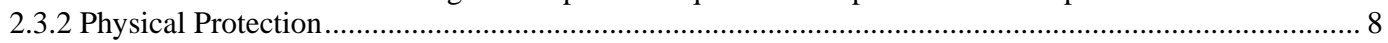

Concerns about radioactive materials security and management .............................................................. 8

3. STEPS INDUSTRY COULD CONSIDER IN THEIR SELF-GOVERNANCE / SELF-REGULATION PROGRAMS ...... 8

3.1 Steps that all industry categories can consider to promote nonproliferation ..................................8

3.1.1 A company could add nonproliferation as a tenet of its governance structure, making it part of its corporate culture and brand.

3.1.2. An industry (or industry association) could engage one or more of the international organizations focused on Corporate Governance to encourage them to include nonproliferation as a principle in their codes/standards/framework

3.1.3 Industry could help states meet their United Nations Security Council Resolution (UNSCR) 1540

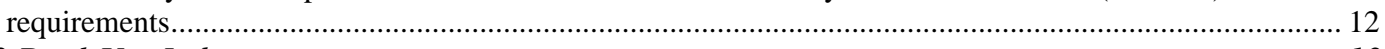

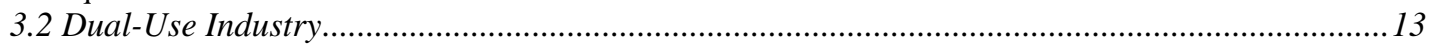

3.2.1 Engagement of companies within an industry to share best practices ................................................... 13

3.2.2 Industry reporting of suspicious export requests to state authorities and the IAEA …….........................13

3.2.3 Training by industry of government export control officials............................................................... 15

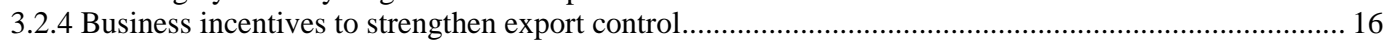

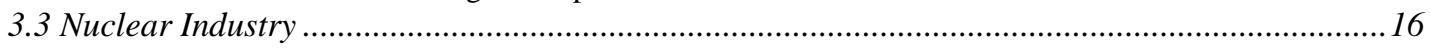

3.3.1 Sharing of information on how prepared an emerging nuclear power state is to receive nuclear power

components involved in building a nuclear power plant ........................................................................ 17

3.3.2 Exchange of information on suspected illegitimate end-users to inform evaluation of completeness of state declarations

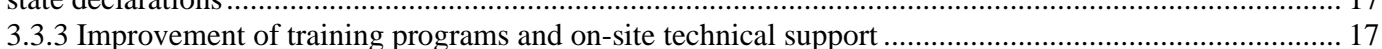

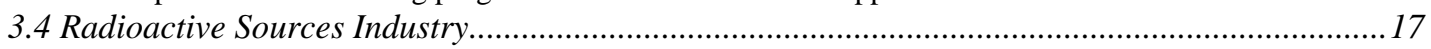


3.4.1 Broadening of ISSPA’s Code of Good Practice ................................................................................ 17

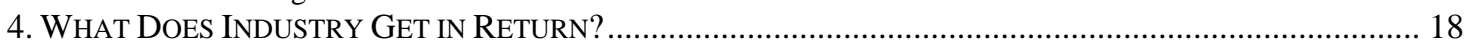

5. INDUSTRY's SELF-REGULATION APPROACHES AND INDUSTRY's REACTION TO THE CONCEPT ............ 18

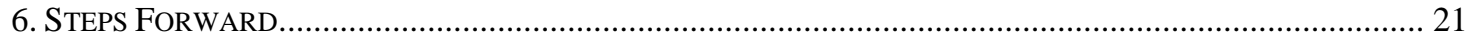

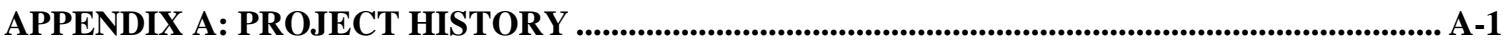

APPENDIX B: ORGANIZATIONS INTERVIEWED ..................................................................1

APPENDIX C: INDUSTRY INTERVIEW PROTOCOL .....................................................................

APPENDIX D: OVERVIEW OF NONPROLIFERATION REGIME ............................................. D-1

\section{TABLE OF FIGURES}

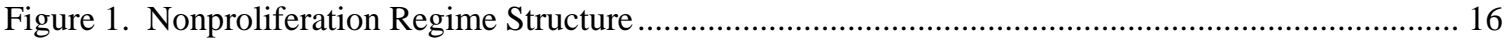

Figure 2. Continuum of Industry Self-Regulation Approaches ....................................................... 19

\section{LiST OF TABLES}

Table 1. Legal Drivers and Responsible Entities for Nonproliferation Regime ..................................... D-2 


\section{EXECUTIVE SUMMARY}

Broadening industry governance to support nonproliferation could provide significant new leverage in preventing the spread/diversion of nuclear, radiological, or dual-use material or technology that could be used in making a nuclear or radiological weapon. Industry is defined broadly to include the nuclear industry, dual-use industries, and radioactive source manufacturers and selected radioactive source-user industries worldwide. Such industry support could be helpful to governments and to industry itself. Just as industry adoption of sustainable environmental standards ${ }^{1}$ helped restore public confidence in the chemical sector following the Bhopal accident, industry adoption of excellent nonproliferation practices could increase public support for expanded use of nuclear power.

This report explores the intersection of three pillars of nonproliferation-export control, physical protection, and safeguards - and three categories of industry - nuclear, dual use, and radioactive sources. International regimes, laws, regulations, and policies exist for each of these three pillars, and government is the lead in administering them (see Table 1 in Appendix D). These three pillars apply to the three industries to varying degrees. (See Figure 1$)^{2}$ The nuclear industry is subject to all three pillars. The radioactive sources industry is subject to export control and physical protection requirements. While the dual-use industry is only technically subject to export-control requirements, it is concerned about protecting its goods throughout the supply chain, including when the items are stored at a facility. Furthermore, reporting of dual-use export information to the International Atomic Energy Agency (IAEA) could be relevant to evaluating the completeness of state declarations and, thus, could contribute to the effectiveness of international safeguards.

This paper describes the relevance of industry governance/self regulation to each of the three categories of industries. The paper concludes that industry can be an important first line of defense in detecting and thwarting proliferation, such as an illicit trade network or an insider theft case, by complementing and strengthening existing governmental efforts. This potential contribution appears to differ for each industry and pillar. For example, the dual-use industry can play a critical role by providing export, import, or security-control information that would allow a government or the IAEA to integrate this information with safeguards, export, import, and physical protection information it has to create a more complete picture of the potential for proliferation.

\footnotetext{
${ }^{1}$ For example, ISO 14001 standard for environmental management (www.iso.ch - ISO 14001 Library). The United Nations (UN) Global Compact includes 10 principles derived from UN and international declarations on labor, human rights, and the environment (www.unglobalcompact.org/Portal/). Other examples of related codes, standards, and frameworks can be found in the World Business Council for Sustainable Development's “Issue Management Tool: Strategic Challenges for Business,” prepared by AccountAbility for the World Business Council for Sustainable Development Accountability and Reporting Working Group, October 2004. None of these codes, standards, or frameworks as currently written includes nonproliferation as a principle.

2 The two-tiered foundation of this figure is comprised of the domestic and international treaties, laws, regulations, and policies that feed into these pillars supporting nonproliferation.
} 
Because industry is closest to users of the goods and technology that could be illicitly diverted throughout the supply chain, industry information can potentially be more timely and accurate than other sources of information. Industry is in an ideal position to help ensure that such illicit activities are detected. This role could be performed more effectively if companies worked together within a particular industry to promote nonproliferation by implementing an industry-wide governance/self-regulation program. Performance measures would be used to ensure their materials and technologies are secure throughout the supply chain and that customers are legitimately using and/or maintaining oversight of these items. This approach is broader than internal compliance programs (ICPs) implemented by individual companies within an industry. While an ICP focuses narrowly on a system a particular company has developed to ensure and promote compliance with existing regulations, industry governance/self regulation contains ICPs in a broader form in that it includes industry-wide approaches for contributing to nonproliferation.

The thesis described in the above paragraph builds on findings from research in progress. More work is needed to determine the interests of particular industries in such self regulation. To date, Pacific Northwest National Laboratory has conducted four case studies of other industries that have adopted a self-regulation approach ${ }^{3}$ as well as a legal analysis of industry self regulation to determine where the greatest benefits could be gained. ${ }^{4}$ Based on this work, interviews were conducted primarily with dual-use industry representatives, trade associations, and relevant non-governmental organizations (NGOs) to determine their interest in the concept. The focus to date has been on export control and physical protection. This research led the authors to conclude that industry support of international safeguards' objectives should be added given the role the nuclear industry plays and the dual-use industry could play in providing information to the IAEA in evaluating the completeness of state declarations.

Nonproliferation is the overarching driver that industry needs to consider in adopting and implementing a self-regulation approach. A few foreign companies have begun such an approach to date; it is believed that, ultimately, broad engagement of global industry leaders in self regulation is needed to result in the greatest nonproliferation benefit. More interviews with nuclear industry representatives, outreach to radioactive source industry representatives, and further research are needed to determine whether enough industry players are willing to adopt self regulation to make it an effective contributor to nonproliferation.

\footnotetext{
${ }^{3}$ These industries included the diamond industry, the fertilizer industry, the chemical industry and the cement industry. See Hund, Gretchen and Oksana Elkhamri, "Industry Self-Regulation as a Means to Promote Nonproliferation,” A Pacific Northwest Center for Global Security Publication, PNNL-15355, October 2005.

${ }^{4}$ Morris, Frederic and Gretchen Hund. "Legal Analysis: Scope for Industry Self-Regulation under Existing Nuclear Export Control and Physical Protection Laws,” A Pacific Northwest Center for Global Security Publication, PNNL-16349, February 2007.
} 


\begin{tabular}{|c|c|}
\hline AEA & American Electronics Association \\
\hline BIS & Bureau of Industry and Security \\
\hline BNFL & British Nuclear Fuels Ltd \\
\hline C-TPAT & Customs-Trade Partnership against Terrorism \\
\hline CSR & Corporate Social Responsibility \\
\hline CPPNM & Convention on the Physical Protection of Nuclear Material \\
\hline DAE & Department of Atomic Energy \\
\hline DOC-BIS & Department of Commerce-Bureau of Industry and Security \\
\hline DOC & Department of Commerce \\
\hline DOE & U.S. Department of Energy \\
\hline EAR & Export Administration Regulations \\
\hline ENSRA & European Nuclear Security Regulators Association \\
\hline EPCI & Enhanced Proliferation Control Initiative \\
\hline GAO & Government Accountability Office \\
\hline GE & General Electric \\
\hline HP & Hewlett Packard \\
\hline ICOTT & Industry Coalition on Technology Transfer \\
\hline IAEA & International Atomic Energy Agency \\
\hline ICP & Internal Compliance Program \\
\hline INFCIRC & Information Circular \\
\hline INMM & Institute for Nuclear Materials Management \\
\hline ISIS & Institute for Science and International Security \\
\hline ISO & International Organization of Standardization \\
\hline ISSPA & International Source Suppliers and Producers Association \\
\hline NA-21 & $\begin{array}{l}\text { National Nuclear Security Administration’s Global Threat } \\
\text { Reduction Initiative }\end{array}$ \\
\hline NAICS & North American Industry Classification System \\
\hline NGO & Non-governmental Organization \\
\hline NPC & Nuclear Power Corporation \\
\hline NPT & Nuclear Nonproliferation Treaty \\
\hline NRC & Nuclear Regulatory Commission \\
\hline NSG & Nuclear Suppliers Group \\
\hline NTI & Nuclear Threat Initiative \\
\hline OECD/NEA & $\begin{array}{l}\text { Organisation of Economic Cooperation and Development/ Nuclear } \\
\text { Energy Agency (OECD/NEA) }\end{array}$ \\
\hline P.A.E.I. & Professional Association of Exporters and Importers \\
\hline PNNL & Pacific Northwest National Laboratory \\
\hline RPTAC & $\begin{array}{l}\text { Regulations and Procedures Technical Advisory Committee } \\
\text { Materials }\end{array}$ \\
\hline TAC & Technical Advisory Committee (of DOC BIS) \\
\hline UNGC & United Nations Global Compact \\
\hline UNSCR & United Nations Security Council Resolution \\
\hline WBCSD & World Business Council for Sustainable Development \\
\hline
\end{tabular}


WCO

WHO

WINS

WMD
World Customs Organization

World Health Organization

World Institute for Nuclear Security

Weapons of Mass Destruction 


\section{What May Prompt Industry to Adopt an Industry Governance/Self-Regulation Approach?}

Drivers that may prompt industry to consider adopting an industry governance/self-regulation approach are similar for all three industry categories covered in this report. Therefore, no distinction of the industries is made below.

\subsection{Concern About Ripple Effect From One Company’s Misdeed}

All three industries covered in this report could be affected by one company's misdeed having a ripple effect onto another company in the same industry. ${ }^{5}$ In one interview the industry representative mentioned that this issue does "keep them awake at night," but there are cases where this ripple effect has not occurred, at least concerning export violations. While there has been overall strong enforcement of export-control laws, the representative offered the example of the defense/aerospace industry, and one example of a fine on a particular company, in which neither the company nor the industry saw a great deal of "blow back." 6 Nonetheless, public reaction to a nuclear industry misdeed might be expected to be harsher because of ongoing fears of nuclear mistakes. Therefore, adopting some type of industry governance/self-regulation approach would help promote expanding its prominence as an energy source worldwide.

\subsection{Possible Regulatory Relief}

Another incentive for all three industry categories may be that a company, and even an industry, may avoid less-intrusive regulations in the future or at least have more flexibility in how it meets particular regulations if it shows a commitment to nonproliferation through participation in a voluntary program.

\subsection{Possible Improved Relations with Regulators}

An additional incentive for implementing a self-regulation approach based on a nonproliferation principle could be the potential for improved relations with the regulators. Their enhanced trust might result in a less adversarial approach to their oversight of industry's activities that they are concerned might lead to security breaches and/or nefarious export requests. Again, this incentive would be relevant to all three industry categories.

\footnotetext{
${ }^{5}$ This was a major driver in several of the case studies reviewed (e.g., Bhopal with the chemical industry).

${ }^{6}$ Comment made during interview with General Electric (GE) representatives, Interview February 2007.
} 


\subsection{Fear of Getting Caught}

A major driver voiced in the interviews for possible adoption of nonproliferation-related governance/self regulation was the fear of getting caught by regulators in an export violation or the fear of an insider diversion of sensitive material or technology (see Appendix C). These fears might only prompt companies to implement better internal compliance programs (ICPs), but could also prompt companies to undertake a more comprehensive industry-wide approach to self regulation. Although this driver could be relevant to all three industry categories, to date, interviews have primarily been with dual-use industry representatives because the team believes they have the most to gain from establishing and adopting a self-regulation approach. ${ }^{7}$ Oerlikon Leybold Vacuum, ${ }^{8}$ a leading German manufacturer of vacuum technology used in many state-of-the-art manufacturing processes, including uranium enrichment, has adopted compliance standards that - at the time of introduction — exceeded those of the German government. The company has also taken on a corporate identity based on being a responsible corporate citizen in matters of export control and nonproliferation. When asked whether Oerlikon had conducted a financial cost/benefit analysis before making the decision to take these actions, Mark Filtz, the Export Control Manager at Oerlikon Leybold Vacuum USA in Export, Pennsylvania, replied:

No one ever sat down and compared the dollar figures. The company made the decision to create the database, do the training, and make it part of our culture. The company doesn't put this in terms of what we can gain, but what we can lose. You don't just want to comply, you want to be proactive. ${ }^{9}$

Ralf Wirtz, the Head of Global Trade Control for Oerlikon in Germany, estimates that Oerlikon Leybold Vacuum—between 1993 and 2003—- lost approximately 25 million Euros solely in component sales (voluntarily rejected sensitive inquiries), but maintains that the benefits outweigh the lost sales. ${ }^{10}$

\subsection{Interest by Corporate Boards to Adopt Governance Standard Covering Nonproliferation}

Corporate boards may increasingly see the value of their companies adopting corporate governance standards that include a code of conduct or ethics based on nonproliferation. Such a shift would be more substantive than simply updating an ICP and would be

\footnotetext{
${ }^{7}$ Morris and Hund. 2007. Findings were that the three areas that could benefit most from considering a self-regulation approach were 1) dual-use export control, 2) security of radioactive sources, and, possibly, 3) physical protection of dual-use items.

${ }^{8}$ Oerlikon-Leybold Vacuum is a German company that sold vacuum components to Iraq, Pakistan, and South Africa in the last century, thereby aiding their unsafeguarded nuclear programs. The Pacific Northwest National Laboratory team conducted interviews first with Mark Filtz, the Export Control Manager of Oerlikon-Leybold Vacuum in Export, PA, and later with Ralf Wirtz, Oerlikon's Head of Global Trade Control for Oerlikon's operations worldwide, located in Germany.

${ }^{9}$ Mark Filtz. Oerlikon-Leybold USA. Interview. 21 September 2007.

${ }^{10}$ Ralf Wirtz. Interview. 11 November 2007.
} 
relevant to all three industry categories. British Nuclear Fuels Ltd. (BNFL) made this decision, which is described under the section on Steps Industry Could Consider (Section 3).

\subsection{Increased Market Value from Adopting an Industry Governance/Self-Regulation Approach}

Another incentive that is applicable to all three industry categories is that there may be a competitive advantage for a company to adopt such an approach because the market values nonproliferation and the company's market share increases. This has been the case with companies that have adopted related programs, such as an Environmental Management System that is certified by a third party. ${ }^{11}$ Similarly, over 200 companies have joined the World Business Council for Sustainable Development (WBCSD), which promotes transparent reporting of practices and companies that embrace sustainable development. $^{12}$ As a whole, industries commissioned studies through the WBCSD to determine ways to improve their practices so that they maintain a more sustainable approach. Even skeptical companies of a WBCSD industry initiative have been known to join the initiative because they were more concerned about being left out and having their shareholders see them as laggards. In the nonproliferation realm, one can see that companies could have a similar perspective of wanting to participate because of actual benefits or at least because they do not want to be seen as caring less about nonproliferation and terrorism than their competitors. Such would be the case for all three categories of industries covered in this report.

\section{Problem or Need Being Addressed}

Unlike the last section where the drivers for adopting an industry governance/self-regulation approach were similar for the three industry categories covered in this report, this section describes the problems and./or needs confronted by each industry category according to each of the relevant nonproliferation pillars-export control, safeguards, and physical protection.

\subsection{Dual-Use Industry}

\subsubsection{Export Control}

Inadequate verification of end-user ("Catch-All” Controls do not always work)

David Brown of Berkeley Nucleonics ${ }^{13}$ pointed to the challenge in accurately identifying the final end user of an export as the single largest need in existing regulatory

\footnotetext{
${ }^{11}$ ISO 14001(www.iso.ch - ISO 14001 Library).

${ }^{12}$ www.wbcsd.org

${ }^{13}$ Berkeley Nucleonics is a U.S. company that exported and attempted to export shipments of nuclear pulse generators to the Department of Atomic Energy (DAE) and the Nuclear Power Corporation (NPC) in India, without the required licenses. At the time of the export—between 1998 and 2000, DAE and NPC were both on the Department of Commerce-Bureau of Industry and Security's Entity List, and exports to DAE and NPC required prior authorization.
} 
infrastructure. ${ }^{14}$ Ralf Wirtz of Oerlikon suggested caution in transactions with business partners who are themselves not the end users of the technology or equipment they seek to purchase. ${ }^{15}$ Both pointed to the clear gap in government regulation or oversight that exists when it comes to middlemen, and Wirtz emphasized the need to demand evidence from the middleman concerning the end user, at least for core technologies that are indispensable for nuclear enrichment and military applications, with a focus on weapons of mass destruction (WMD) and carrier systems capable to deliver these. These middlemen as front companies can make the diversion of industrial equipment or illicit procurement hard to detect.

To address the problem of end-user verification, Department of Commerce-Bureau of Industry and Security (DOC-BIS) implemented the Enhanced Proliferation Control Initiative (EPCI), essentially consisting of what are known as "catch-all" controls. "Catch-all" controls, which are "designed to deny exports to end-users or end-uses directly or indirectly related to all aspects of the manufacture of nuclear weapons, reactors and fuels, and so forth,” place responsibility on the exporter to apply for a license when he/she knows or is informed by the U.S. Government that the end use or end user of a shipment is unauthorized. ${ }^{16}$ The principle of the controls is that the Bureau of Industry and Security (BIS) has information on the end use or end user rather than depending only on licensing-based information on the capabilities of the equipment or technology.

Ralf Wirtz pointed out that one reason why these "catch-all" controls do not always work is that an adversary knows the regulations and can find a way to circumvent them. A typical example is the use of technologies that do not involve licensable goods. David Brown mentioned that diversion of goods can occur from shipments to foreign nationals within the United States. He saw this as an area that needs to be addressed by some type of industry-government cooperation.

Many companies to whom Oerlikon Leybold Vacuum refused to export its goods made requests that seemed suspicious or the end user was not clearly known. These companies continue to be surprised that Oerlikon Leybold Vacuum would decline their business. Most middlemen, Wirtz explained, are initially surprised, but after a few minutes of conversation and Wirtz's clarification of what is at stake, the middleman typically revises his thinking. According to Wirtz, 98 percent of the time, the person understands the issues, respects the decision, and goes and does his/her homework and returns to Oerlikon with the specifics to buy the product. ${ }^{17}$

At the same time, however, Mark Filtz and Ralf Wirtz both expressed what they saw as a striking lack of compliance in small companies, stating that many violations take place

\footnotetext{
${ }^{14}$ David Brown. Interview. 8 November 2007.

${ }^{15}$ Ralf Wirtz. Interview. 11 November 2007.

${ }^{16}$ Nilsson, Brian H., "'Catch All’ Controls: The United States Perspective,” September 28, 2000, presentation on U.S. Department of Commerce, Bureau of Industry and Security, website www.bis.doc.gov/news/archive2000/nilssonsoxfordspeech.htm.

${ }^{17}$ Ralf Wirtz. Interview. 11 November 2007.
} 
willfully. They stated that regardless of how many requests they deny, another company will always step in to supply the desired product. As Mark Filtz expressed, "[i]t amazes me how little compliance there is... Oerlikon Leybold Vacuum is unique."18

Insufficient information exchange by industry on suspicious inquiries or suspected front companies

The knowledge gathered by a company during its compliance activities is not typically shared among companies or with international bodies, such as the International Atomic Energy Agency (IAEA). Again, Oerlikon Leybold Vacuum's practices are beyond the norm in this regard. The company provides information to the appropriate German authorities when it receives a suspicious inquiry as well as to the IAEA. The same procedure is applied in other countries where the company is active.

The logic behind this cooperation is that an inquiry that Oerlikon Leybold Vacuum believes is sensitive is just one piece of a larger puzzle. If more companies would share their information, the authorities would be more productive in verifying their analyses. Mr. Wirz said, "[t]he vacuum components that we refuse to deliver today need not be digged [sic] out of the desert sand somewhere else by UN inspectors in 10 or 15 years from now, or never be detected..."19

The interviews with U.S. industry conducted in this study, although by no means complete, did not identify similar information sharing occurring in the United States, either with the regulatory authority or with the IAEA. The closed nature of industry generally inhibits such information exchange on all levels because of concerns about loss of proprietary information.

\subsubsection{Safeguards}

Reporting of information that could help inform IAEA in its evaluation of the completeness of a recipient state's declarations

The dual-use industry can contribute indirectly to strengthening safeguards through the exchange of information with the U.S. Government and the IAEA. Industry shares export information on suspected illegitimate nuclear end-users or related suspicious requests through the above "catch-all" provision with the federal government. In addition, industry could provide this same information to the IAEA (as Oerlikon Leybold Vacuum does), to be integrated with existing information to create a more complete picture of the potential for proliferation. The IAEA could use the information to determine the completeness of the recipient state's declarations. Companies could decide to do this individually or they could share the information with an independent, industry-led organization whose job it is to track this information for a particular dual-use industry and provide the information to the IAEA. This organization would be expected

\footnotetext{
${ }^{18}$ Mark Filtz. Oerlikon-Leybold USA. Interview. 21 September 2007.

${ }^{19}$ Ralf Wirtz. Interview. 11 November 2007.
} 
to keep company-specific information confidential for proprietary reasons. The organization could report on trends, best practices, etc., to its member companies. The challenge is deciding the scope of an industry organization given that there are so many different industries that fall into the dual-use category. Could there be one such organization to cover all dual-use industries or would each industry (e.g., photonics and optics) need its own organization? Regardless, the U.S. dual-use industries would need to work with the relevant U.S. government representatives to determine the appropriateness of its sharing such information with the IAEA.

\subsection{Nuclear Industry}

\subsubsection{Export Control}

Need to thoroughly review emerging nuclear states' and associated utilities' preparedness to accept nuclear power components, build a reactor, and/or operate a reactor that they have requested

The IAEA developed its Milestones document ${ }^{20}$ to help emerging nuclear states recognize all the steps required to commence a nuclear power program in their state. Once the state requests bids on the components, it would be helpful if not only the responsible exporting state agency makes a readiness determination but also the nuclear supplier, which is likely more familiar with the request and overall program involved in the determination. Ideas about possible forms this coordination could take and sharing among nuclear companies is included in the Steps Industry Could Take section (Section 3).

Insufficient information exchange on suspicious inquiries or suspected front companies

Although this problem/gap was based on interviews with dual-use industry representatives, it is not difficult to see how it would also be relevant to the nuclear industry. The section on Steps Industry Could Take (Section 3) describes possible steps for the industry that could contribute to more efficient and effective disruption of illicit trade.

\subsubsection{Safeguards \\ Reporting of information that could help inform IAEA in its evaluation of the completeness of a recipient state's declarations}

The U.S. nuclear industry does not have a significant domestic role in international safeguards because, as a nuclear weapon state, the U.S. participates in safeguards voluntarily, and only a few facilities are subject to safeguards at any one time. However, nuclear exporters can contribute indirectly to strengthening safeguards through the

\footnotetext{
${ }^{20}$ IAEA, Milestones in the Development of a National Infrastructure for Nuclear Power, NE Series Guide NG-G-3.1, 2007, http://www-pub.iaea.org/MTCD/publications/PDF/Pub1305_web.pdf
} 
exchange of information. As with dual-use industries, if the nuclear industry was to share information on suspected illegitimate nuclear end users or suspicious requests with the federal government and the IAEA, this information could then be integrated with existing safeguards-relevant information to create a more complete picture of the potential for proliferation by a recipient state/company. Since U.S. companies do not normally report information to the IAEA, if they chose to do so, they could provide supplemental information that could be used in IAEA state-level evaluations for a country. For example, if during a recipient facility visit, industry notices that an IAEA canister seal had been illegally removed, industry could report this to the IAEA. As with the dual-use industries, nuclear exporters could decide to do this individually or they could share the information with an independent, industry-led organization whose job is to track this information and provide a broader, more-detailed picture to the IAEA. This organization could report on trends, best practices, etc., to its member companies. The U.S. nuclear industry would need to work with the relevant U.S. government representatives to determine the appropriateness information sharing with the IAEA.

\subsubsection{Physical Protection \\ Concerns about nuclear materials security and management}

Potentially, the nuclear industry can play an important role in enhancing the physical protection of nuclear materials. The Nuclear Threat Initiative (NTI) and the Institute for Nuclear Materials Management (INMM) have raised concerns about nuclear materials security and management, particularly in reference to operators of facilities that manage highly enriched uranium and plutonium on-site and in transit. These organizations identified a lack of training programs and on-site technical support for nuclear security, and further perceive the need for assistance with self-assessment of physical protection, material control, and accounting systems. Their main concern is with foreign held and shipped highly enriched uranium and plutonium. However, it is envisioned that U.S.-relevant entities would be part of an organization designed to provide the support and responsibility for implementing the agreed-upon best practices agreed (See discussion on the World Institute of Nuclear Security (WINS) in section on Steps Industry Could Consider [Section 3]).

Roger Howsley, who was once Director of Security, Safeguards, and International Affairs at BNFL asserts that staff can become complacent about the potential for proliferation simply because no incident has occurred. He argues that because "nothing happens" (no serious incidents), there are no performance data available to judge the effectiveness of the security system. ${ }^{21}$

\subsection{Radioactive Sources Industry}

No interviews have been conducted to date that target the radioactive source industry. This gap is included in Steps Industry Could Consider (Section 3). Nonetheless, the team

\footnotetext{
${ }^{21}$ Howsley, Roger. “Civil Nuclear Security - More Regulation or Better Corporate Governance?” Given at Nuclear Inter Jura Congress, 1-5 October 2007, Session V - Nuclear Security.
} 
believes that the following are problems that could benefit from the industry taking a self-regulation/industry-governance approach to address them. This assertion will require validation through future interviews.

\subsubsection{Export Control}

Insufficient information exchange on suspicious inquiries or suspected front companies

Although this problem/gap was based on interviews with dual-use industry representatives, it is not difficult to see how it would also be relevant to the radioactive sources industry. Given the sheer number of sealed sources that are in use and shipped on a routine basis, a rigorous, industry-driven program to identify and report illicit requests would likely be helpful. The International Source Suppliers and Producers Association (ISSPA) has a Code of Good Practice objectives and principles. The principles include a provision to make "key information for source tracking purposes available to the appropriate regulatory authorities," but no explicit stipulation is made for sharing questionable requests or other related information among industry members. ${ }^{22}$ Radioactive source companies will be concerned about sharing proprietary information with competitors, so this would need to be avoided. However, in cases of suspicious requests, sharing information should not be a problem.

\subsubsection{Physical Protection \\ Concerns about radioactive materials security and management}

The radioactive sources industry has been working to enhance the physical protection of its radioactive materials. As mentioned above, the ISSPA has a Code of Good Practice that includes objectives and principles for ensuring safety and security throughout the lifecycle of sealed sources. This is encouraged of individual companies, but more benefit may result if sharing of information occurs among association members to communicate best practices and further enhance physical protection.

\section{Steps Industry Could Consider in its Self-Governance/Self-Regulation Programs}

There are a number of steps that the three industry categories could take to enhance governmental efforts to prevent proliferation. Those steps that are relevant to all industry categories are described first, followed by a discussion of steps specific to a particular industry category.

\subsection{Steps that all industry categories can consider to promote nonproliferation}

3.1.1 A company could add nonproliferation as a tenet of its governance structure, making it part of its corporate culture and brand.

\footnotetext{
${ }^{22}$ www.isspa.com/practice/htm
} 
An article in The Economist describes companies that embed Corporate Social Responsibility (CSR) into their operations, making it "part of the corporate DNA."23 Many companies have adopted CSR as a fundamental part of their corporate identity; primarily, their focus has been on environmental and social or ethical responsibility. Companies could consider broadening their CSR programs to include nonproliferation.

There is a significant challenge in ensuring a company's supply chain-including its extended network of companies and suppliers-considers CSR. In fact, 60 percent of the 2000 large companies surveyed (as part of The Economist study) reported that they fail to require their suppliers to enforce a code of conduct. ${ }^{24}$ As The Economist suggests, companies should put in place appropriate systems for monitoring risk across the supply chain, maintaining good channels of communication throughout the chain, and auditing each other's compliance with ethics codes. ${ }^{25}$

Adopting nonproliferation as part of the "corporate DNA" would require the implementation of a series of governance changes. At the company level, a board of directors could decide to explicitly include nonproliferation as a principle in a company's governance structure.

Roger Howsley is promoting such an approach, and asserts that "security performance must become an integral part of the corporate governance arrangements for all civil nuclear organizations." ${ }^{26}$ He argues for a system of benchmarking (as is done through the World Association of Nuclear Operators for safety improvements) so relevant organizations have guidelines for effective security measures. He also suggests sharing good practices. Howsley argues that the corporate board should establish an Executive Committee on Security.

This concept could be broadened to have companies consider adding an Executive Committee on Nonproliferation. For a nuclear industry company, the committee would cover physical protection, export control, and safeguards. For the dual-use industry, companies with significant, relevant exports could also have such a committee. Radioactive source manufacturers and/or users might also add nonproliferation to their governance structure to help monitor nonproliferation through supply chains.

Following on Howsley's notion, but focusing on nonproliferation instead of merely security, this committee would then appoint a Director of Nonproliferation for the overall company, whose job would include conducting assessments of the company's practices and reporting findings regularly to the board. Each site would provide monthly performance reports, and an annual assurance report would be formally signed off by the relevant site director. The Director of Nonproliferation would receive these reports and be responsible for conducting an independent assessment of them and then endorsing the

\footnotetext{
${ }^{23}$ The Economist. “Just good business.” 19 January 2008, p. 4.

${ }^{24}$ Ibid.

${ }^{25}$ The Economist. ”A stitch in time.” 19 January 2008, p. 13.

${ }^{26}$ Howsley, Roger. “Civil Nuclear Security - More Regulation or Better Corporate Governance?” Given at Nuclear Inter Jura Congress, 1-5 October 2007, Session V - Nuclear Security.
} 
reports before submission to the board. The Director of Nonproliferation would also maintain a nonproliferation risk register that the board would then approve as part of the annual review. ${ }^{27}$

When BNFL's nuclear services business was operational ${ }^{28}$, it voluntarily sent its security reports to the United Kingdom's national regulator with explanations for any identified deficiencies and full details of all enhancement actions. ${ }^{29}$ The thresholds for all key performance measures were intentionally set very low to encourage the reporting of minor events. Prior to 9/11, BNFL spent about $£ 30$ million a year on its program, and added an additional $£ 25$ million after the 9/11 attacks. ${ }^{30}$ Howsley notes that the European Nuclear Security Regulators Association (ENSRA) serves a useful purpose in having regulators compare notes on good practices. Additionally, the IAEA works with state authorities to help improve their standards, but neither is a substitute for what Howsley is suggesting; that is, for the practitioners to network with one another to improve overall security. ${ }^{31}$

Companies in each of the industries covered in this report could consider a similar approach to BNFL, but broaden the monitoring, networking, and reporting to include all relevant pillars of nonproliferation. In addition, each industry as a whole could consider options for sharing its approaches through a relevant industry association or new entity (see the discussion of the World Institute for Nuclear Security in the next section).

David Albright from the Institute for Science and International Security (ISIS) called for industry to take more of an active role in monitoring its exports to verify end users so that situations like the illicit trading via the A.Q. Khan network can be interrupted. He worked closely with Ralf Wirtz from Oerlikon Leybold Vacuum, who advocates a "voluntary self-restraint program." Wirtz describes this program as more at the core of a company's persona; it is more fundamental than sharing best practices. Albright and Wirtz served on panels ${ }^{32}$ encouraging industry to consider adopting a similar program surrounding their dual-use products and export control. This focus is somewhat similar to the broadening of corporate governance described here, but does not include physical protection and safeguards nor the nuclear or radiological industry.

3.1.2. An industry (or industry association) could engage one or more of the international organizations focused on Corporate Governance to encourage them to include nonproliferation as a principle in their codes/standards/framework.

\footnotetext{
${ }^{27}$ Adapted from Howsley, 2007.

${ }^{28}$ See BNFL website at http://www.bnfl.com. Press release from Dec. 18, 2007 says that "BNFL has today agreed to sell its specialist nuclear services business, Project Services, to VT Group plc.”

${ }^{29}$ Howsley, Roger. “Civil Nuclear Security - More Regulation or Better Corporate Governance?” Given at Nuclear Inter Jura Congress, 1-5 October 2007, Session V - Nuclear Security.

${ }^{30}$ Ibid.

${ }^{31}$ Ibid.

${ }^{32}$ For example, 2007 Carnegie International Nuclear Nonproliferation Conference, Panel: Finding Innovative Ways to Detect and Thwart Illicit Nuclear Trade, June 26, 2006. http://www.carnegieendowment.org/events/index.cfm?fa=eventDetail\&id=1029
} 
The industries covered in this report could work through the International Organization of Standardization (ISO) 26000 Guidance focused on CSR to determine its interest in adding a principle focused on nonproliferation. As this guidance standard is to be published in 2010, there is some time to influence the wording of the standard if industry is interested. ${ }^{33}$

The United Nation Global Compact (UNGC) is a United Nations initiative aimed at fostering international progress and stability. ${ }^{34}$ The Global Compact sets out 10 principles that address issues of human rights, the labor market, environmental protection, and the battle against corruption. Thus, the initiative establishes a framework for economic, ecological, and social sustainability. Since mid-2003, Oerlikon has been a member of the UNGC, stands by its principles, and actively implements those principles within the scope of its commercial activities. The UNGC does not include nonproliferation as one of its principles, but the group could be lobbied to do so. ${ }^{35}$

The industries could also lobby international trade organizations to determine their interest in including nonproliferation as a component of their institutional culture. There could be an immense multiplying effect if they were to become involved. As mentioned, one such venue is ISSPA, which could be approached to determine its interest in broadening its Code of Good Practice. ${ }^{36}$ Radiological sources are used in various industries and are transported around the world on a regular basis. The National Nuclear Security Administration's Global Threat Reduction Initiative (NA-21) hosted discussions with source users from the oil drilling industry and found them to be interested in self regulation. NA-21 in partnership with the oil exploration industry successfully developed an industry best practices document for addressing the security and control of high-risk radioactive sources for the oil industry. ${ }^{37}$

WBCSD published "Issue Management Tool: Strategic Challenges for Business,” which was prepared by AccountAbility for the WBCSD Accountability and Reporting Working Group. ${ }^{38}$ It is a comprehensive report that lists all the related codes, standards, and frameworks in terms of how they work and what themes they cover. ${ }^{39}$ Nine different codes are covered, but none of them include nonproliferation. The WBCSD could be engaged to determine its interest in including nonproliferation as a principal for its institution and for working with relevant industries.

WINS was recently established and is focused on sharing and implementing best practices for nuclear material security worldwide. The target is on facility operators

\footnotetext{
${ }^{33}$ http://isotc.iso.org/livelink/livelink/fetch/2000/2122/830949/3934883/3935096/home.html?nodeid=44512 59\&vernum $=0$

${ }^{34}$ http://www.unglobalcompact.org

35 This was a suggestion made by Ralf Wirtz. Interview. 11 November 2007.

36 This is a plan for follow-on work.

${ }^{37}$ The best practices guidelines were finalized in September 2008. Work is continuing to assist the industry in implementing these guidelines.

38 http://www.wbcsd.org/plugins/DocSearch/details.asp?type=DocDet\&ObjectId=MTIwNjg

39 http://www.wbcsd.org/plugins/DocSearch/details.asp?type=DocDet\&ObjectId=MTIwNjg
} 
managing highly enriched uranium and plutonium, not on the broader field of dual-use and radiological material and technology, including export control. WINS could also be approached to determine its interest in taking on this greater scope in engaging industries.

In the case of other industries that have undertaken a self-regulation approach (i.e. fertilizer, chemical, diamond), the respective industry took action in response to a trigger that would have hurt individual companies and the industry as a whole. The nuclear, radioactive sources and dual-use industries have an incentive to prevent such a trigger from occurring (e.g., terrorist attack using a dirty bomb). Presumably, such an event would have a crippling effect not only on the individual company that supplied the material—knowingly or not—but on the industry in its entirety. That such an incident has not yet occurred may slow progress on the development and implementation of an industry standard, but will not detract from its importance. These industries would seem to have a clear incentive to ensure that such an incident does not occur.

3.1.3 Industry could help states meet their United Nations Security Council Resolution (UNSCR) 1540 requirements.

UNSCR 1540 includes requirements on the various pillars of nonproliferation outlined in this report. The Resolution calls upon all states to" take and enforce effective measures to establish domestic controls to prevent the proliferation of nuclear, chemical, or biological weapons and their means of delivery, including by establishing appropriate controls over related materials and to this end shall:

a) Develop and maintain appropriate effective measures to account for and secure such items in production, use, storage or transport;

b) Develop and maintain appropriate effective physical protection measures;

c) Develop and maintain appropriate effective border controls and law enforcement efforts to detect, deter, prevent and combat, including through international cooperation when necessary, the illicit trafficking and brokering in such items in accordance with their national legal authorities and legislation and consistent with international law;

d) Establish, develop, review and maintain appropriate effective national export and trans-shipment controls over such items, including appropriate laws and regulations to control export, transit, trans-shipment and re-export and controls on providing funds and services related to such export and trans-shipment such as financing, and transporting that would contribute to proliferation, as well as establishing end-user controls; and establishing and enforcing appropriate criminal or civil penalties for violations of such export control laws and regulations." 40

Paragraph (a) speaks to safeguards, paragraph (b) addresses physical protection, and paragraphs (c) and (d) address export control. Because UNSCR 1540 is a United Nations

\footnotetext{
${ }^{40}$ UN Security Council Resolution 1540 (2004). Section 3 (a-d). http://www.un.org/Docs/sc/unsc_resolutions04.html
} 
resolution, it is more broadly binding than other multinational treaties (e.g., Nuclear Nonproliferation Treaty (NPT)) and conventions that are voluntarily joined by states.

Resolution 1540 could serve as an effective mechanism for industry engagement in nonproliferation. This would be of most interest for states interested in complying but lack a rigorous nonproliferation regime structure. UNSCR 1540 calls on states to engage industry to "develop appropriate ways to work with and inform industry and the public regarding their obligations under such laws." ${ }^{11}$ Implementation and enforcement of 1540 is a work in progress, but it is clear that industry could have an important role in helping states meet their requirements. The 1540 Committee could also reach out to engage industry to think about self regulation on nonproliferation.

\subsection{Dual-Use Industry}

\subsubsection{Engagement of companies within an industry to share best practices.}

Elizabeth Turpen and Brian Finley from the Henry L. Stimson Center are researching means to disrupt illicit trafficking networks by mobilizing the industrial business community to embrace nonproliferation. ${ }^{42}$ They suggest working with the dual-use industry to design a template of information that industry could collect to help identify potential illicit trafficking networks. Industry would be encouraged to implement these practices. $^{43}$

\subsubsection{Industry reporting of suspicious export requests to state authorities and the IAEA.}

Interviews have identified industry information sharing with state regulatory authorities and/or the IAEA as a critical need in existing efforts to stem WMD proliferation. The authors believe the lack of information exchange among companies or with international bodies, such as the IAEA, inhibits the degree to which suspicious end-users are identified and exports to them prevented. With regard to export control, ideally, industry would be more proactive in sharing suspicious requests with the relevant state regulatory authorities (e.g., BIS within the United States) and potentially with IAEA to enable prevention or detection of proliferation.

\footnotetext{
${ }^{41}$ UN Security Council Resolution 1540 (2004). Section 8 (d). http://www.un.org/Docs/sc/unsc_resolutions04.html

${ }^{42}$ Henry L. Stimson Center. "Industry and Illicit Networks: Mobilizing the Business Community as Partners in Nonproliferation,” A Concept Paper prepared by the Stimson Center.

${ }^{43}$ Turpen and Finlay have also recently published a report that proposes a public-private partnership model as a mechanism to integrate and serve nonproliferation, economic development, and other US foreign policy goals. The model would initially focus on strengthening existing nonproliferation programs aimed at redirecting former Soviet weapons scientists by creating incentives for private companies to employ these scientists. The model could then be expanded to other areas of proliferation concern. http://www.stimson.org/pub.cfm?ID=602
} 
The team spoke with Keith Melchers, Export Compliance Manager at Hewlett Packard (HP), ${ }^{44}$ who is Chairman of the DOC-BIS Regulations and Procedures Technical Advisory Committee (RPTAC). This Committee advises the Department of Commerce (DOC) on the technical parameters for export controls applicable to dual-use commodities and technology and on the administration of those controls. It is one of several Technical Advisory Committees (TACs) that bring together representatives from industry and government representing diverse points of view on the concerns of the exporting community. Melchers clarified that RPTAC is made up of industry representatives selected from firms producing a broad range of goods, technologies, and software presently controlled for national security, foreign policy, nonproliferation, and short supply reasons or that are proposed for such controls. The committee is balanced to the extent possible among large and small firms. ${ }^{45}$ Melchers indicated that, ideally, the number of companies taking part in RPTAC committee would be expanded. ${ }^{46}$

Elizabeth Turpen at the Stimson Center concurred that the RPTAC is attempting to update export-control regulations and guidelines "based on how things are today.",47 Melchers pointed out that the regulations, including the nonproliferation regulations, are updated on an ongoing basis. Although some parts have not been updated in 10years, it is important to note that the regulations are dynamic and not static. The regulations also apply to electronic trade. ${ }^{48}$

Oerlikon reported that the sensitive inquiries and export denials it makes and shares with the IAEA are treated as "highly confidential information." Prior to contributing to the Trade and Technology Analysis System, Wirtz verified that the data his company would supply were safe. He also confirmed that the security system was a strong enough wall between the data base where the proprietary information is kept and the more general, publicly-available data bases held by the IAEA. He felt that the concern over loss of proprietary data was not valid. More importantly, he feels that it is the right thing to do. What is discouraging is Oerlikon's comment that the majority of their denials are shopped to their competitors who fill the orders. "There is almost always one who will supply..."49

It would be interesting to determine whether U.S. dual-use industries would be open to sharing nonproliferation-related information with the IAEA, particularly if they could be convinced that proprietary information would not be released. If there is interest, would U.S. regulators be open to U.S. dual-use industry sharing this information with the IAEA?

\footnotetext{
${ }^{44}$ Hewlett Packard was licensed to sell computers, electronic testing, calibration and computer graphics equipment to the Iraqi Atomic Energy Commission. “Iraq’s Bomb, Chip by Chip.” New York Times, 24 April 1992. Also NTI Chronology of Nuclear Imports. http://www.nti.org/e_research/profiles/Iraq/Nuclear/2124.html

45 http://tac.bis.doc.gov/index.html

${ }^{46}$ Keith Melchers. Interview. 7 December 2007.

${ }^{47}$ Elizabeth Turpen. Interview. 8 January 2008.

${ }^{48}$ Keith Melchers, Interview. 7 December 2007.

${ }^{49}$ Ralf Wirtz. 2007. 11 November 2007.
} 
A recent background report to the May 2008 IAEA “20/20 Vision for the Future” report ${ }^{50}$ appears to be seeing glimpses of such a future. It states:

“...the IAEA foresees a coordinating role in the development of new security related technologies by others and acting as a hub for receiving, disseminating and analyzing information. It will give priority to the exchange and analysis of information on illicit nuclear trafficking and other unauthorized activities, and to developing new information resources and information networks. Partnerships with other international organizations, for example Interpol, OECD/NEA, WCO and WHO, will be further broadened." 51

More specifically, the report recognizes that uncovering covert nuclear trade networks will require new approaches that would be most effective with industry input:

"A worldwide analytical approach cross-referencing all nuclear trade relevant information will be required. To detect attempts to acquire nuclear material and technology, the IAEA needs information from States, particularly with regard to procurement inquiries and export denials. Information on suspicious orders received, but not filled, by private companies provides valuable early information." 52

A recent Pacific Northwest National Laboratory (PNNL) report ${ }^{53}$ raises the point that the Nuclear Suppliers Group (NSG) does not share information on denials with the IAEA, and that only a few NSG states do so on a voluntary basis. Even with states bringing an Additional Protocol into force, information sharing is limited to exports of nuclear trigger list items and, therefore, does not provide for dual-use items. Industry could coordinate with its federal regulator to share such information with the IAEA to further the IAEA's nonproliferation effectiveness. As indicated previously, the IAEA will likely need to demonstrate its ability to protect this information such that proprietary information is not leaked.

\subsubsection{Training by industry of government export control officials}

In the case of Oerlikon Leybold Vacuum, German export officials often contact Oerlikon for insights into relevant, suspicious requests. Oerlikon provides vacuum technology and application training to these officials. Facilitating such a positive relationship-a security partnership-between government and industry in the United States would enhance

\footnotetext{
${ }^{50}$ IAEA, "20/20 Vision for the Future: Background Report by the Director General for the Commission of Eminent Persons.” February 2008. p. 28.

${ }^{51}$ Ibid, p. 18.

${ }^{52}$ Ibid, p. 21.

${ }^{53}$ Goorevich, Richard, Rich Hooper, Danielle Peterson, Lawrence Scheinman, and J.W. Tape. "Exploring the Issue of Integrating Export Control and International Safeguards," prepared by the PNNL Center for Global Security for the National Nuclear Security Administration,” PNNL-16498. April 2007.
} 
nonproliferation. One possibility, following the Oerlikon example, could be training that companies provide to export-control officials to familiarize them with their products.

\subsubsection{Business incentives to strengthen export control}

One interviewee, Remy Nathan, is with the American Electronics Association (AEA), also a member of the Coalition for Security and Competitiveness. He indicated that DOC is attempting to create business incentives to strengthen export-control mechanisms. For instance, with the validated end-user concept, DOC has approached China and India, telling them that if they wish to acquire more sensitive technologies, they must provide evidence that those to whom U.S. industry is supplying the technology are valid and verifiable end users. ${ }^{54}$

\subsection{Nuclear Industry}

Three pillars support the nonproliferation regime structure for the nuclear industry: export control, safeguards, and physical protection (See Figure 1).

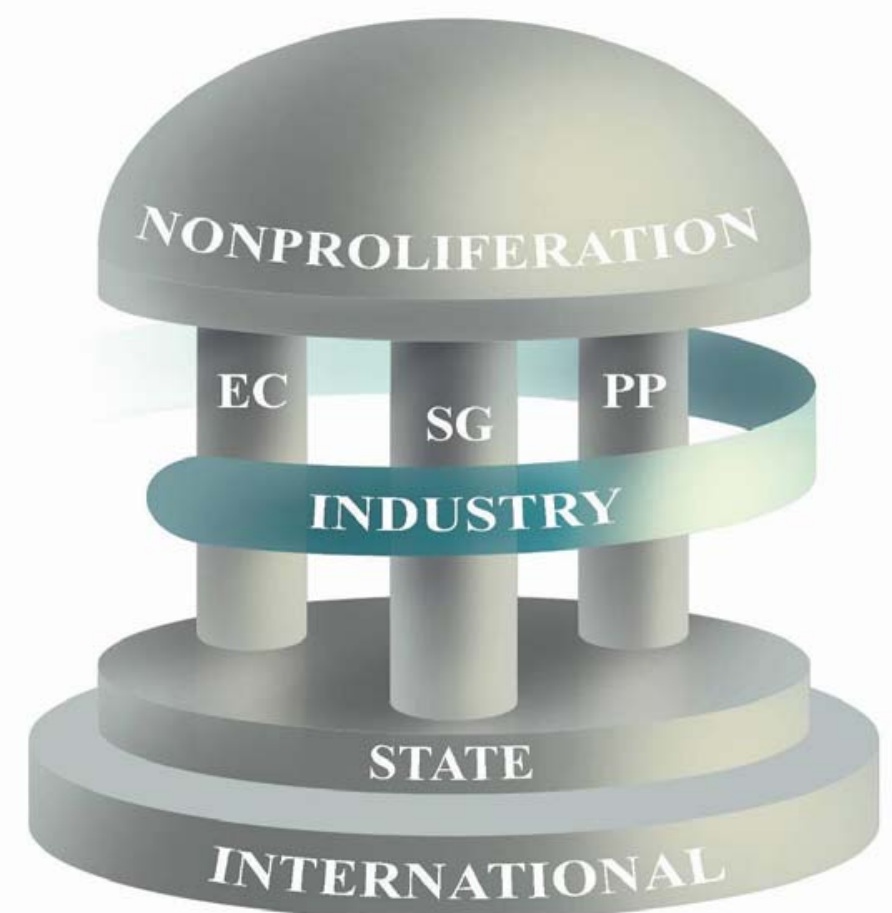

Export Control (EC) Safeguards (SG) Physical Protection (PP)

Figure 1. Nonproliferation Regime Structure

\footnotetext{
${ }^{54}$ Nathan Remy. Interviewed on 13 December 2007. More work is needed to determine dual-use industry’s interest in physical protection as well as export control.
} 
3.3.1 Sharing of information on how prepared an emerging nuclear power state is to receive nuclear power components involved in building a nuclear power plant

Nuclear suppliers could be motivated to ensure that the buyers of their goods (i.e., those that are to be used in building a nuclear power plant) are capable of safely and securely managing the materials. These suppliers may have staff onsite in the emerging nuclear state who would be in a good position to verify that sufficient infrastructure exists prior to exporting the goods. These suppliers do not want to have an accident or diversion occur because the ripple effect would be devastating to the nuclear renaissance. Under a self-regulation approach, all nuclear suppliers could agree to share their information on state preparedness with the IAEA.

3.3.2 Exchange of information on suspected illegitimate end-users to inform evaluation of completeness of state declarations

With respect to export control and safeguards, the nuclear industry can help contribute to strengthening safeguards by providing information to their federal government and, subsequently, with the IAEA on suspected illegitimate end users or suspicious export requests. This information could contribute to the IAEA's evaluation of the completeness of the recipient state's declarations. As mentioned under the dual-use industry section (Section 2.1), federal regulators may be nervous in having industry reporting directly to the IAEA. As such, suppliers might coordinate with their federal government before providing the information to the IAEA.

\subsubsection{Improvement of training programs and on-site technical support}

The nuclear supplier industry can improve physical protection by providing recipients with training programs and on-site technical support on nuclear security as well as assist companies with self-assessment of physical protection and material control and accounting systems. NTI and the INMM are spearheading the establishment of a new international organization - the World Institute for Nuclear Security - to work with countries to improve security on nuclear materials, especially highly enriched uranium and plutonium.

\subsection{Radioactive Sources Industry}

\subsubsection{Broadening of ISSPA's Code of Good Practice}

With respect to export control, the ISSPA's Code of Good Practice could be broadened to not only inform the regulator but also each other about suspicious requests or suspected front companies so that the entire industry knows who to look out for. The ISSPA could 
design the data base such that proprietary information of reporting companies would be kept confidential.

Physical protection could be enhanced by ensuring that best practices shared among companies (likely through the ISSPA) are followed throughout the lifecycle of managing sealed sources. Companies could strengthen their own compliance programs by leveraging lessons learned and the experiences of other companies. This would be particularly important for small companies that lack the resources to devote to building strong compliance programs.

\section{What Does Industry Get in Return?}

Because it could avoid losses in profits and reputation if the program is successful in ensuring that misdeeds do not occur, industry could decide to adopt a self-regulation program. Industry could also avoid having further onerous regulations placed on it by showing its proactive interest in participating in a voluntary program. Industry's explicit commitment could also lead to more flexibility in how it undertakes nonproliferation commitments. Another benefit could be improved relations with the regulators, trust being built, and more of a teamed approach with the regulator in identifying questionable activities that raise concerns about security breaches and/or nefarious export requests.

An industry (and the companies within it) that adopts a self-regulation program based on a nonproliferation principle could gain market share from the nonproliferation brand. The market could respond positively and companies adopting the program would improve their market position and have their share of the market increase. This has been the case with companies that have adopted related programs, such as an Environmental Management System, that is certified by a third party. ${ }^{55}$ The Global Reporting Initiative is another program that has helped companies that have adopted the Sustainability Reporting Guidelines, which are designed for organizations to disclose their sustainability performance around economic, environmental, and social parameters. ${ }^{56}$ Shareholders appreciated the ability to evaluate companies based on these types of guidelines. Companies have generally seen positive returns to their bottom line-as well as their reputation - from having adopted one of these sets of codes, guidelines, and/or frameworks. Nonproliferation could easily be included in the societal parameter.

\section{Industry's Self-Regulation Approaches and Industry's Reaction to the Concept}

A range of self-regulation approaches could be considered by industry. Ideally, a dedicated industry (e.g., nuclear) would consider establishing and adopting a self-regulation approach based on nonproliferation versus a single company. Such was the case with the chemical industry following the Bhopal accident when the industry created Responsible Care. Following the Oklahoma bombing incident, the fertilizer

\footnotetext{
55 ISO 14001(www.iso.ch - ISO 14001 Library).

${ }^{56}$ http://www.globalreporting.org/Home
} 
industry created its program, called Product Stewardship. In response to a public outcry concerning conflict diamonds being sold, the diamond industry created the Kimberly Process to register diamonds. Finally, the worldwide cement industry started its Sustainability Initiative in reaction to concern about its carbon dioxide emissions and the impact on global climate change. ${ }^{57}$

Approaches that industry could consider are illustrated in Figure 2. These options, running from the least to the most aggressive (from left to right), range from a Code of Conduct or Ethics at one end to a more rigorous certified standard that would be required, issued, and monitored by a third party, such as those granted authority through the ISO, at the other end to ensure compliance. ${ }^{58}$

\begin{tabular}{|c|c|c|c|c|c|}
\hline 7 & $\downarrow$ & $\downarrow$ & $\downarrow$ & $\downarrow$ & $\downarrow$ \\
\hline $\begin{array}{l}\text { Code of } \\
\text { Ethics/Code } \\
\text { of Conduct }\end{array}$ & $\begin{array}{l}\text { Industry-Wide } \\
\text { Organization } \\
\text { (NGO): Establish } \\
\text { Program }\end{array}$ & $\begin{array}{l}\text { Working Groups } \\
\text { Set Policy/ } \\
\text { Guidelines }\end{array}$ & $\begin{array}{c}\text { Organization } \\
\text { Establishes } \\
\text { Procedures \& } \\
\text { Reporting System }\end{array}$ & $\begin{array}{c}\text { Establish ISO } \\
\text { Guidence }\end{array}$ & $\begin{array}{l}\text { ISO Standards with } \\
\text { Certification \& Third } \\
\text { Party Verification }\end{array}$ \\
\hline
\end{tabular}

Figure 2. Continuum of Industry Self-Regulation Approaches

The number of company interviews has been limited in number and range. However, the responses received from individuals who were asked for feedback on whether an industry self-regulation approach was worth pursuing included the following:

- "Maybe ,but it becomes more appealing if industry receives some benefit in return." (GE) $)^{59}$

- "We already have a rigorous Internal Compliance Program (ICP) and don't know what more this would provide us, but keep us in the loop."(GE) $)^{60}$

- "Government nonproliferation regulations are already in place and have primacy so is there a need?" (HP) ${ }^{61}$

- “Sounds interesting, but I don't have time to take it on; my company is too small. We work aggressively on our own compliance issues, which is already quite time consuming. I'd like to stay in the loop." (Berkeley Nucleonics) ${ }^{62}$

- "Absolutely, but I wouldn't call it industry self regulation or best practices, this needs to be bigger than that; we use the term 'voluntary self restraint' but it needs

\footnotetext{
${ }^{57}$ Hund, Gretchen and Oksana Elkhamri, "Industry Self-Regulation as a Means to Promote Nonproliferation,” A Pacific Northwest Center for Global Security Publication, PNNL-15355, October 2005.

${ }^{58}$ Ibid.

${ }^{59}$ Del Renigar, Patricia Campbell, Bryce MacDonald and Kathleen Palma. Interview. February 2007.

${ }^{60}$ Ibid.

${ }^{61}$ Keith Melchers. Interview 7 December 2007.

${ }^{62}$ David Brown. Interview. 8 November 2007.
} 
to be presented as an overarching business philosophy." (Oerlikon Leybold Vacuum) $)^{63}$

- "There is concern about information sharing regarding end-user and other proprietary information because for reasons of competition companies don't like to reveal their company data base." (HP) ${ }^{64}$

- "Industry doesn't want to be seen working hand in hand with government; there's the concern about civil liberties." (Stimson Center) ${ }^{65}$

- "Companies don't want to be held liable: if a government entity picks up all the pieces of information that otherwise would have wound up in the wastebasket, synthesizing this information could become a 'one stop shopping' outlet. Companies don't want to be sued by an entity because of inferences the government made based on information they gave it.” (Stimson Center) ${ }^{66}$

- "Such a program would not succeed unless it is a management priority. (HP) ${ }^{67}$

- "Perception could be that cost is prohibitive and it would entail added administrative burden." (HP) ${ }^{68}$

The distinction between an ICP and industry self regulation was not immediately clear to the GE representatives interviewed. Upon greater discussion, the distinction was noted, but the GE representatives expressed concern over the proprietary nature of their ICP. ${ }^{69}$ GE mentioned that the company's policies require screening customers before shipping a sensitive item, and the company tracks government watch lists. GE stated that the government should offer incentives for industry to embrace a self-regulation approach (e.g., expediting certain types of license approvals). When asked how it would evaluate the effectiveness of a self-regulation program, GE said it would do a self-assessment, to evaluate how well it is monitoring its operations to insure that nonproliferation goals are met. GE representatives were open to a third-party assessment if the third party signed a confidentiality agreement with companies so that the specifics or results were not shared, for competitive reasons. A third-party provider could collect best practices from doing these reviews. This would provide a real service to the participants and result in a useful collection of informal guidance. The GE representatives indicated that industry export or import brokers would be a good target for the self-regulation approach.

David Brown from Berkeley Nucleonics, a much smaller company, talks frequently with three to four larger companies in his field to keep him apprised of export issues. He seeks them out at compliance conferences or by telephone. The process is quite informal.

As mentioned, Ralf Wirtz is the lead at Oerlikon advocating a concept similar to nonproliferation industry governance/self regulation ${ }^{70}$ to all levels and subsidiaries of the

\footnotetext{
${ }^{63}$ Ralf Wirtz. Interview. 11 November 2007.

${ }^{64}$ Keith Melchers. Interview 7 December 2007.

${ }^{65}$ Elizabeth Turpen. Interview. 8 January 2008.

${ }^{66}$ Ibid.

${ }^{67}$ Keith Melchers. Interview. 7 December 2007.

${ }^{68}$ Ibid.

${ }^{69}$ Del Renigar, Patricia Campbell, Bryce MacDonald and Kathleen Palma. Interview. February 2007.

${ }^{70}$ Wirtz calls the concept "voluntary self restraint" but it encompasses many of the themes of nonproliferation.
} 
company worldwide. He indicated that the company would soon be hiring an export-control manager to oversee all U.S. subsidiaries. He advocated presenting the concept as an overarching business philosophy where personal responsibility is a key consideration. In Germany, Wirtz pointed out a legal requirement that top company officials (chief executive officers, chief operating officers, or chief financial officers) responsible for exporting licensable goods are personally responsible for a violation that takes place under their tenure. Institutionalizing this responsibility, Wirtz argues, would go a long way in strengthening industry compliance with existing regulations and,। potentially, in promoting a self-regulation approach. He also advocates for compliance staff of a corporation to have the necessary resources to do their job. "A good, well funded and equipped internal compliance system is the best insurance.”,71

\section{Steps Forward}

The interviews conducted to date and further research into linkages between safeguards and export control ${ }^{72}$ led the team into thinking that the scope of industry governance/self regulation needed to include safeguards as the third pillar, with export control and physical protection, to provide effective coverage of nonproliferation (see Figure 1) for the nuclear industry.

More interviews are needed to validate and refine the findings for each of the three main industry categories - nuclear, dual use, and radioactive sources. Particularly, more interviews are needed with the nuclear and radioactive sources industries. With respect to the radioactive sources industry, the team would look to build on NA-21's effort. In addition to GE, nuclear companies must be interviewed to determine their interest in establishing and adopting a corporate governance structure that includes nuclear nonproliferation with all three pillars.

Future interviews would specifically determine industry’s interest in:

a) sharing best practices with companies within its industry

b) reporting suspicious export requests to state authorities and the IAEA

c) interfacing with government more openly to identify innovative ways to strengthen nonproliferation practices

d) adding nonproliferation as a tenet of its governance structure, making it part of its corporate culture and brand

e) lobbying one or more of the international organizations focused on Corporate Governance to have them include nonproliferation as a principle in their codes/standards/framework.

Keith Melchers from HP, who is chair of the BIS RPTAC, recommended contacting DOC's BIS lead for the RPTAC to present the concept of industry self regulation to RPTAC.

\footnotetext{
${ }^{71}$ Ralf Wirtz. Interview. 11 November 2007.

${ }^{72}$ Goorevich, et al, 2008.
} 
The team would also look to collaborate with NGOs interested in this topic to further collaboration between industry and government. A future workshop could be held to raise awareness of the principles of industry self regulation on nonproliferation and to discuss the five topics above as well as to discuss other forums offered for ways to implement a self-regulation program. 


\section{Appendix A: Project History}

PNNL pursued a multi-year, industry self-regulation research agenda to investigate options that industry might want to consider in establishing and adopting a self-regulation approach. Several case studies were conducted of other industries that have adopted a self-regulation approach to identify the drivers behind these decisions and the challenges and benefits they faced from having done so. ${ }^{73}$

As part of this effort, two reports were written for $^{74}$ and two papers presented at the Institute for Nuclear Materials Management (INMM) annual conference. ${ }^{75}$ The second report and INMM paper analyzes the legal issues involved in industry adopting a self-regulation approach. ${ }^{76}$ This work identifies three areas where industry self regulation could make a significant contribution to export control and physical protection: 1) dual-use export control, 2) security of radioactive sources, and, possibly, 3) physical protection of dual-use items. Excerpts from the second INMM paper include: ${ }^{77}$

1. Dual-use export controls in the United States rely on the regulated community to take the initiative and determine whether to seek a license from the DOC's BIS for a particular export. As a General Accountability Office (GAO) report noted, "the U.S. government increasingly relies on industry to determine whether an export needs to be licensed, even though industry has raised questions about its capability and willingness to make this assessment without government support." 78 Accordingly, a self-regulatory initiative in the form of model compliance programs as well as guidance and support in making initial determinations as to whether an export license should be sought could be beneficial.

As mentioned, BIS's RPTAC is attempting to update export-control regulations and guidelines, which were written 10 years ago. This is a good step, but the challenge is increasing awareness of all dual-use industry that regulations exist and to have them implemented.

\footnotetext{
73 These industries included the diamond industry, the fertilizer industry, the chemical industry, and the cement industry. See Hund, Gretchen and Oksana Elkhamri, "Industry Self-Regulation as a Means to Promote Nonproliferation,” A Pacific Northwest Center for Global Security Publication, PNNL-15355, October 2005.

${ }^{74}$ Hund and Elkhamri, October 2005 and Morris, Frederic and Gretchen Hund. "Legal Analysis: Scope for Industry Self-Regulation under Existing Nuclear Export Control and Physical Protection Laws,” A Pacific Northwest Center for Global Security Publication, PNNL-16349, February 2007.

${ }^{75}$ Hund, Gretchen. "Nonproliferation Promoted by Industry Self-Regulation,” in the Proceedings of the Institute of Nuclear Materials Management $46^{\text {th }}$ Annual Conference held in Nashville, TN, July 17-20, 2006 and Morris, Frederic and Gretchen Hund. "Scope For Industry Self-Regulation Under Existing Nuclear Export Control And Physical Protection Requirements and Guidance” in the Proceedings of the Institute of Nuclear Materials Management 47th Annual Meeting held in Nashville, TN, July 16-20, 2007.

${ }^{76}$ Morris and Hund, February 2007 and July 2007.

${ }^{77}$ Morris and Hund, July 2007.

${ }^{78}$ U.S. General Accounting Office, Weapons of Mass Destruction: Assessing U.S. Policy Tools for Combating Proliferation, GAO-02-226T (November 2001), http://www.gao.gov/new.items/d02226t.pdf. Quoted from previous paper.
} 
2. Security from malicious acts is generally a new concern to users of radioactive sources, such as irradiators, hospitals, industrial radiographers, and the drilling industry. The Nuclear Regulatory Commission's (NRC) regulations, called Increased Controls, on these sources are quite general and performance-oriented. Practically applying these requirements to sources in use at a fixed facility, in use at a remote jobsite, or in transport may not always be straightforward. While the Increased Controls are too new ${ }^{79}$ to expect industry to have developed best practices or some "beyond compliance" guidance, it is very likely that at least some users of radioactive sources would benefit from guidance on how best to meet these new requirements within a given practice area, such as industrial radiography or nuclear medicine. Accordingly, one or more self-regulatory initiatives for this purpose could be beneficial.

The team plans to interview both NRC officials and industry leads to validate this could be a beneficial area of focus for industry self regulation. This effort would build on NA-21's Global Threat Reduction Initiative work.

3. Historically, dual-use goods are subject only to export controls and have not been controlled by specific physical protection requirements (which apply to nuclear material and facilities). For at least some dual-use items, there could be a nonproliferation benefit from industry voluntarily implementing physical protection requirements on these items to help ensure that they are not stolen or illicitly transferred to end users who are not qualified for legal transfer. Because the industries and companies involved would be similar to those that are candidates to participate in industry self regulation with respect to dual-use export controls, the use of physical protection requirements could be synergistic when it comes to nonproliferation with the export-controls effort.

Given that two of three findings above pointed to the importance of engaging the dual-use industry, the PNNL team first worked at segmenting the dual-use industry. The team started with the North American Industry Classification System (NAICS) classification, ${ }^{80}$ which lists the following industries:

1. photonics and optics

2. robotics

3. manufacturing, machinery, and tools

4. chemical industry

5. materials

6. electronics/instrumentation.

\footnotetext{
${ }^{79}$ Order was issued December 2005, requiring full compliance by May 2006.

${ }^{80}$ Based on Elkhamri, Oksana, November 2006. "Industry Associations in Stemming Nuclear Dual-Use Trade,” internal paper that segmented the dual use market into various sectors.
} 
The team also turned to the NSG guidelines governing the export of nuclear-related dual-use items and technologies. The NSG Annex II list contains six major sections, which do not precisely correspond to the NAICS list. The sections include the following:

1. industrial equipment

2. materials

3. uranium isotope separation equipment and components ${ }^{81}$

4. heavy water production plant-related equipment

5. test and measurement equipment for the development of nuclear explosive devices

6. components for nuclear explosive devices.

The team identified individual companies that fell into either of these lists that had a past history of supplying dual-use goods or technologies to sensitive countries, ranging in size from small businesses to large, multinational companies. Companies without such histories were also interviewed. The team's interest was in determining these industry representatives' perspective on the adequacy of existing export-control and physical-protection mechanisms to combat proliferation networks. They were also asked their opinions on establishing a self-regulation approach. A list of the companies interviewed is provided in Appendix B.

A major challenge comes with trying to approach the dual-use industry to determine its interest in a self-regulation approach based on nonproliferation. The team found that while many trade organizations exist that bring together individual companies in the various dual-use industries, a focus on nonproliferation was lacking. Several address export-control compliance and hold seminars and workshops to this end, but none consider nonproliferation as a standard similar to environmental ethics or other measure of corporate social responsibility. Several of these trade associations and other organizations have the potential, however, to serve as an organizing center for industry self regulation of the dual-use industries.

Relevant industry trade associations that correspond to the listings above were also identified as prospects to interview because they could serve as a gauge of current industry discussion and awareness of export-control and physical-protection issues and provide insight into any intra-industry discussion on best practices, particularly concerning supply chain security. These associations typically consist of representatives from private companies in the same or similar industries that convene on issues of common interest, often promoting a single stance on issues of policy relevance. They hold workshops, seminars, and conferences that bring together representatives for education, training, and other purposes. Such associations could potentially serve as a conduit for broader industry engagement in a self-regulation approach. A listing of the most relevant associations is provided in Appendix B.

Finally, NGOs were identified that are undertaking similar studies of industry-government cooperation to promote nonproliferation. Interviews with

${ }^{81}$ Other than trigger list items 
representatives from these organizations were also conducted. A description of these NGOs is also provided in Appendix B.

Many of the suggestions heard from these interviewees were summarized above, under Section 3-Steps Industry Could Consider. Appendix C is a generic copy of the interview protocol used in conducting the interviews. Appendix D is an overview of the nonproliferation regime that includes the legal drivers and responsible entities at both the state and international level for export control, safeguards, and physical protection. Under each of these three sections, the drivers and entities are described, when relevant, for nuclear material and facilities, nuclear-related dual-use items, and radioactive sources. 


\section{APPENDIX B: ORgANIZATIONS INTERVIEWED}

$\underline{\text { Individual Companies }}$

- Berkeley Nucleonics

- General Electric (GE)

- Hewlett Packard (HP)

- Oerlikon group: Headquartered in Switzerland. The business segment Oerlikon Leybold Vacuum (headquartered in Cologne, Germany) is an enterprise in the field of vacuum technology, solutions, and services.

\section{$\underline{\text { Industry Trade Associations }}$}

- AeA: ${ }^{82}$ According to AeA's website, it is the largest association of high-tech companies in the United States, with about 2500 companies. It represents all segments of the electronics industry and 1.8 million employees. AeA was founded in 1943 as the American Electronics Association. "Dedicated solely to helping its members' top line and bottom line,” AeA lobbies governments at the state, federal, and international levels; "provides access to capital and business opportunities and offers select business services and networking programs.",83 AeA conducts workshops and seminars to better inform its members on U.S. export controls; recent topics have included: "U.S. Export Controls: Recent Trends and Best Practices” and "Best Practices in Global Trade Compliance.”84

- Coalition for Security and Competitiveness: ${ }^{85}$ The Coalition for Security and Competitiveness was launched on March 6, 2007, with the delivery to President George Bush of initial recommendations for enhancing U.S. security and competitiveness by modernizing the U.S. export-control system. Formed by eight leading trade associations, the Coalition seeks to modernize the export-control system so that America is prepared to meet the security and economic challenges of the 21st century. The Coalition believes that a modern export-control system should accommodate the following activities:

o accurately identify and safeguard sensitive and militarily critical technologies

o enhance U.S. technological leadership and global industrial competitiveness through more responsive and efficient regulatory management

o facilitate defense trade and technological exchange with allies and trusted partners

82 http://www.aeanet.org

${ }^{83}$ Ibid.

${ }^{84} \mathrm{http} / / / \mathrm{www}$. aeanet.org/PressRoom/aeamonthlynews1007.asp\#International

${ }^{85}$ http://www.securityandcompetitiveness.org 
o support a strong U.S. technology industrial base and highly skilled workforce

o promote greater multilateral cooperation with U.S. friends and allies on export controls. ${ }^{86}$

- Industry Coalition on Technology Transfer (ICOTT): Founded in 1983, ICOTT is a group of high-technology trade associations whose members are affected by U.S. export controls. ICOTT monitors U.S. export-control regulations on technology transfer.

- Professional Association of Exporters and Importers (P.A.E.I.): ${ }^{87}$ P.A.E.I. is an organization of professionals involved in import/export activities. Conceptualized in May 1986, in response to changes in export license controls, P.A.E.I. was incorporated as a non-profit organization in 1987. P.A.E.I. sponsors quarterly meetings with featured guest speakers, a bimonthly newsletter, networking, and job-placement opportunities. The association's objectives include the following:

0 promoting and fostering the role of the import/export professional

0 providing ongoing education relative to regulatory issues

0 exchanging information

o enhancing industries' participation in import/export control issues and policies. ${ }^{88}$

$\underline{\text { NGOs }}$

- The Henry L. Stimson Center: Brian Finlay and Elizabeth Turpen at the Stimson Center have included the idea of industry self regulation (although not defined as such) in their concept paper "Industry and Illicit Networks: Mobilizing The Business Community As Partners In Nonproliferation.” Over 2 years, they seek to create a task force bringing together industry and government, aimed at industry development of a set of best practices. Their focus is on export controls rather than physical protection. At this point, they are trying to define a client in government, to create a task force of industry leaders to provide rationale, who could act as sales agents on the back end once a standard is defined that is felt to be workable for industry. They have made contact with ISIS and are interested in collaboration.

- Institute for Science and International Security (ISIS): David Albright and his colleagues at ISIS have been working with Ralf Wirtz at Oerlikon Leybold Vacuum to find ways to complement existing governmental regulatory infrastructure with what they term "voluntary self restraint" on the part of industry. In the near term, Albright is seeking to facilitate interaction and

\footnotetext{
${ }^{86}$ Ibid.

${ }^{87}$ http://www.paei.org

${ }^{88}$ Ibid.
} 
increase collaboration on areas of mutual interest between government and industry, particularly on export-control issues. 


\section{ApPendix C: Industry Interview Protocol}

Introduction: Hello, I am Gretchen Hund with the Pacific Northwest National Laboratory and met you at ..... The purpose of my call is to describe an initiative that we are exploring and determine your interest in it. The initiative is Industry Self Regulation. We define this to mean a systematic voluntary program undertaken by an industry or by individual companies to anticipate, implement, supplement, or substitute for regulatory requirements in a given field, generally through the adoption of best practices. We have been evaluating different self-regulation models for export control of nuclear, dual-use, and radiological items and physical protection of nuclear materials and radioactive sources.

The concept is to adopt some form of a self-regulation approach to complement export-control and physical-protection regulations. We have conducted other industry case studies to understand what led them to adopt such an approach and the incentives and constraints they met along the way. We have several take-away lessons from this analysis that, at some point, we would be happy to share.

(If they ask, the cases included the chemical industry, following the Bhopal accident and the industry's creation of Responsible Care, the fertilizer industry after the Oklahoma bombing and its creation of Product Stewardship, the diamond industry based on consumers' concern in buying conflict diamonds and the industry's creation of the Kimberly Process to register diamonds, and the cement industry concerned about its $\mathrm{CO}_{2}$ emissions and impact on global climate change and its Sustainability Initiative.)

\section{What's your reaction to the general idea of Industry Self Regulation?}

2. Do you believe there are any significant gaps in the regulation of exports or security within your industry? What are your views on establishing some type of self-regulation program to help address these possible gaps?

3. Where do you see the greatest need? [Note: Some have argued that the nuclear industry is regulated sufficiently and where the real need is with the vast array of dual-use industries and radioactive source manufacturers/users. May need to describe the industry segmentation we have conducted. If we had to pick areas today, they would be: 1) Dual-Use Export Control, 2) Security of Radioactive Sources, and, possibly, and 3) Physical Protection of Dual-Use Items.]

4. What do you see as the most compelling reasons for establishing a self-regulation model or approach? [Could include: 1) need for effective compliance program managed by industry, and 2) small companies that cannot afford to have a rigorous internal audit program could benefit from industry-led training.] 
5. What do you see as the motivators for industry to consider in adopting a self-regulation approach? [Note: Motivations have included: 1) building confidence on the part of customers, investors, and regulators that the industry is monitoring its activities; 2) adopting approaches that are more efficient/effective than current approaches (and having measures to calculate this); 3) anticipating regulations that could be coming; and 4) obtaining some form of regulatory relief in exchange (e.g., Green Lane program for shippers under C-TPAT (CustomsTrade Partnership against Terrorism) to get their goods inspected more quickly.]

6. What do you see as the greatest constraints? [Could include: 1) regulations have primacy, no need (true for some cases maybe but not all); 2) information protection; 3) lack of perceived need; 4) low management priority; 5) cost; and 6) added administrative burden.]

7. What focus (or multiple foci) of best practices do you think would be most helpful to industry? [Could include: 1) best practices that help to implement regulations, 2) best practices that augment regulations, or 3) best practices that fill in gaps in a regulatory scheme.]

8. How would you envision monitoring the success of a self-regulation program? [Could include: 1) industry doing it itself (self monitoring), 2) third-party certification, 3) regulatory oversight, or 4) some combination.]

9. Are you aware of any discussions within industry about establishing some type of self-regulation approach focused on export control and/or physical protection? [Note: World Association of Nuclear Operators and Institute of Nuclear Power Operations are focused on safety of the nuclear power industry. NTI is investigating the possibility of creating a World Institute of Nuclear Security (WINS), where the focus is currently only on physical protectionsecuring bomb-grade materials wherever they may be.]

10. Would you like to be involved in a future workshop/roundtable to discuss these ideas further with other industry representatives and appropriate government officials? What companies do you see as potential leaders in this area? 


\section{APPENDIX D: OVERVIEW OF NONPROLIFERATION REGIME}

The international nonproliferation regime functions at two mutually reinforcing levels: at the state level and the international level. Since the creation of the Nuclear Nonproliferation Treaty (NPT), a series of mechanisms to prevent illicit development of nuclear weapons have been devised that form the backbone of the international nonproliferation regime. The key elements of this regime-export control, physical protection, and safeguards-are handled differently in each level. Export controls are a state-level function through national laws, regulations, and policies, and an international function through the Nuclear Suppliers Group and its guidelines. Additionally, the International Atomic Energy Agency (IAEA) can use export-control information to enhance its safeguards conclusions if states are willing to provide such information. Physical protection is also a state-level function, but is covered by an international convention, the Convention on the Physical Protection of Nuclear Material (CPPNM). Additionally, the IAEA provides countries with assistance in creating an effective physical protection program. Finally, international safeguards are an international function of the IAEA and are supported by state-level responsibility to provide nuclear program information that the IAEA verifies through its safeguards.

These elements of the regime were introduced at various stages in establishing the international nonproliferation regime and are periodically strengthened in response to perceived shortcomings and gaps in the existing regime as well as challenges to it. Export controls govern the shipment, transmission, or transfer of certain sensitive equipment, technology, information, or software to foreign persons or entities. International safeguards aim to ensure that no nuclear material has been diverted from peaceful use and provide credible assurances regarding the non-existence of undeclared nuclear materials and activities. Physical protection aims to reduce vulnerability of critical infrastructure and key assets from physical attack. Each element is executed by a particular set of actors, summarized below in Table 1, and - to varying extents-addresses nuclear, dual-use, and radioactive materials. 
Table 1. Legal Drivers and Responsible Entities for Nonproliferation Regime

\begin{tabular}{|c|c|c|c|c|c|c|}
\hline & \multicolumn{3}{|l|}{ International } & \multicolumn{3}{|l|}{ United States } \\
\hline & Driver & Entity & Role & Driver & Entity & Role \\
\hline \multirow[t]{3}{*}{$\begin{array}{l}\text { Nuclear material } \\
\text { and facilities }\end{array}$} & $\begin{array}{l}\text { Treaty on the } \\
\text { Nonproliferation } \\
\text { of Nuclear } \\
\text { Weapons (NPT) } \\
\text { Zangger } \\
\text { Committee } \\
\text { Understandings, } \\
\text { INFCIRC/209 }\end{array}$ & $\begin{array}{l}\text { Zangger } \\
\text { Committee }\end{array}$ & $\begin{array}{l}\text { Provides } \\
\text { guidance on } \\
\text { implementation } \\
\text { of NPT Article } \\
\text { III, paragraph } 2\end{array}$ & \multirow[t]{3}{*}{$\begin{array}{l}\text { Export and } \\
\text { Import of } \\
\text { Nuclear Material } \\
\text { and Equipment, } \\
10 \text { CFR part } 110 \\
\text { Assistance to } \\
\text { Foreign Atomic } \\
\text { Energy } \\
\text { Activities, } 10 \\
\text { CFR Part } 810\end{array}$} & \multirow[t]{3}{*}{\begin{tabular}{|l} 
NRC \\
U.S. Department \\
of Energy \\
(DOE)
\end{tabular}} & \multirow[t]{3}{*}{$\begin{array}{l}\text { Licenses and } \\
\text { regulates } \\
\text { export of } \\
\text { nuclear } \\
\text { material and } \\
\text { equipment } \\
\text { Controls expor } \\
\text { of nuclear } \\
\text { technology }\end{array}$} \\
\hline & $\begin{array}{l}\text { Nuclear } \\
\text { Suppliers Group } \\
\text { (NSG) } \\
\text { Guidelines, } \\
\text { INFCIRC/254 } \\
\text { (Part 1) }\end{array}$ & NSG & $\begin{array}{l}\text { Establishes } \\
\text { guidelines on } \\
\text { export of items } \\
\text { especially } \\
\text { designed or } \\
\text { prepared for } \\
\text { nuclear use }\end{array}$ & & & \\
\hline & $\begin{array}{l}\text { United National } \\
\text { Security Council } \\
\text { Resolution } \\
\text { (UNSCR) } 1540\end{array}$ & 1540 Committee & $\begin{array}{l}\text { Promotes } \\
\text { implementation } \\
\text { of UNSCR } 1540\end{array}$ & & & \\
\hline $\begin{array}{l}\text { Nuclear-related } \\
\text { dual use items }\end{array}$ & $\begin{array}{l}\text { NSG } \\
\text { Guidelines, } \\
\text { INFCIRC/254 } \\
\text { (Part 2) }\end{array}$ & NSG & $\begin{array}{l}\text { Establishes } \\
\text { guidelines on } \\
\text { dual-use items } \\
\text { and technology }\end{array}$ & \begin{tabular}{|l} 
Export \\
Administration \\
Regulations \\
(EAR), 15 CFR
\end{tabular} & $\begin{array}{l}\text { Department of } \\
\text { Commerce } \\
\text { Bureau of } \\
\text { Industry and }\end{array}$ & $\begin{array}{l}\text { Licenses and } \\
\text { regulates } \\
\text { export of dual } \\
\text { use item in }\end{array}$ \\
\hline
\end{tabular}




\begin{tabular}{|c|c|c|c|c|c|c|}
\hline $\begin{array}{l}\text { Nuclear-related } \\
\text { dual use items } \\
\text { (continued) }\end{array}$ & UNSCR 1540 & 1540 Committee & $\begin{array}{l}\text { Promotes } \\
\text { implementation } \\
\text { of UNSCR } 1540\end{array}$ & Parts 730-774 & Security (BIS) & $\begin{array}{l}\text { consultation } \\
\text { with DoD, } \\
\text { DOE, and State } \\
\text { Dept. }\end{array}$ \\
\hline \multirow[t]{2}{*}{$\begin{array}{l}\text { Radioactive } \\
\text { Sources }\end{array}$} & $\begin{array}{l}\text { IAEA Code of } \\
\text { Conduct on the } \\
\text { Safety and } \\
\text { Security of } \\
\text { Radioactive } \\
\text { Sources } \\
\text { IAEA Import- } \\
\text { Export } \\
\text { Guidance }\end{array}$ & IAEA & $\begin{array}{l}\text { Develops } \\
\text { guidance, } \\
\text { facilitates } \\
\text { information } \\
\text { exchange, } \\
\text { receives States' } \\
\text { political } \\
\text { commitment to } \\
\text { implement }\end{array}$ & \multirow[t]{2}{*}{$\begin{array}{l}\text { Export and } \\
\text { Import of } \\
\text { Nuclear Material } \\
\text { and Equipment, } \\
10 \text { CFR part } 110\end{array}$} & \multirow[t]{2}{*}{ NRC } & \multirow[t]{2}{*}{$\begin{array}{l}\text { Licenses and } \\
\text { regulates } \\
\text { export of } \\
\text { radioactive } \\
\text { sources }\end{array}$} \\
\hline & UNSCR 1540 & 1540 Committee & $\begin{array}{l}\text { Promotes } \\
\text { implementation } \\
\text { of UNSCR } 1540\end{array}$ & & & \\
\hline
\end{tabular}


Legal Drivers and Responsible Entities for International Safeguards

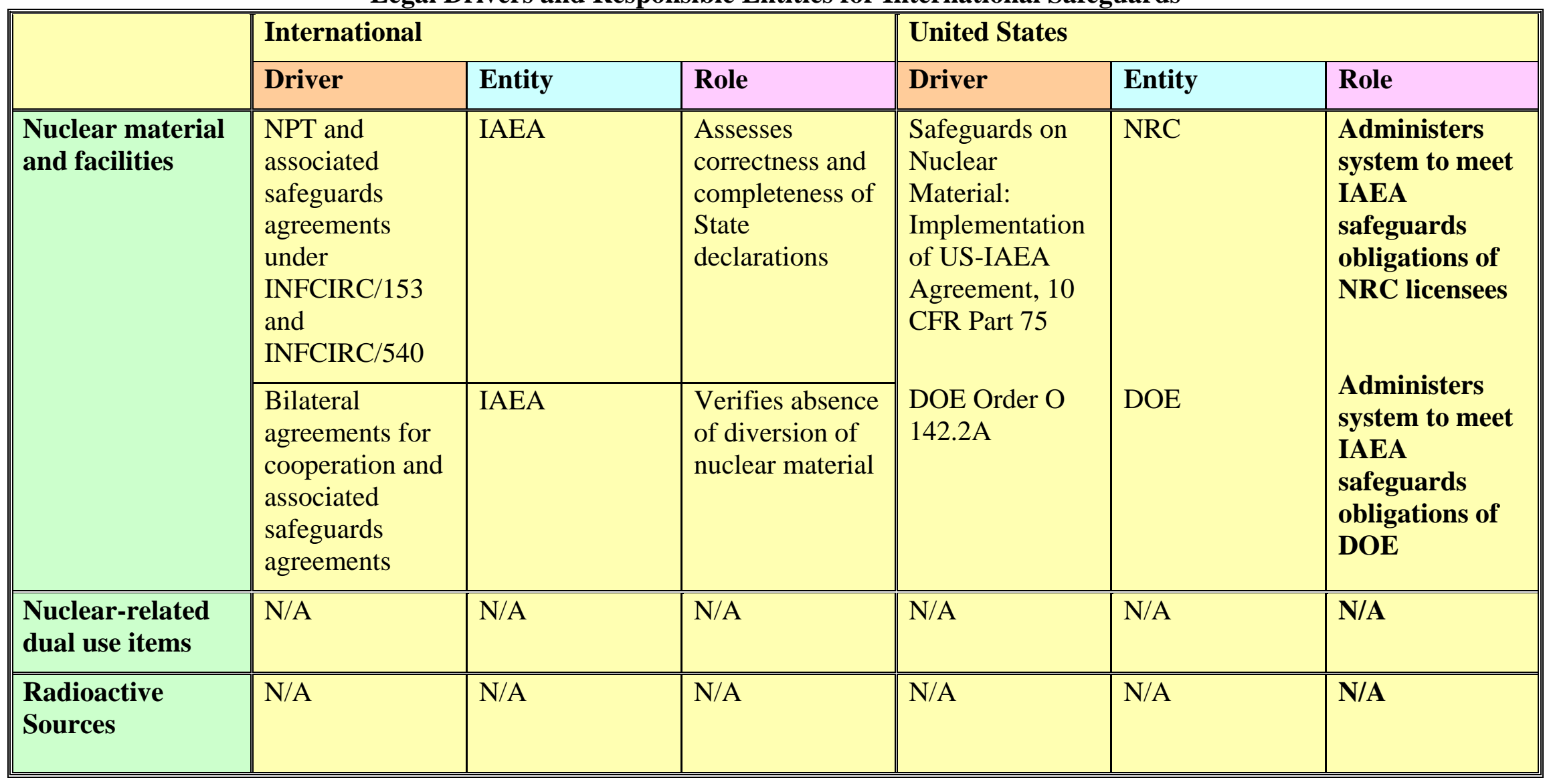


Legal Drivers and Responsible Entities for Physical Protection

\begin{tabular}{|c|c|c|c|c|c|c|}
\hline & \multicolumn{3}{|l|}{ International } & \multicolumn{3}{|l|}{ " United States } \\
\hline & Driver & Entity & Role & Driver & Entity & Role \\
\hline \multirow[t]{3}{*}{$\begin{array}{l}\text { Nuclear material } \\
\text { and facilities }\end{array}$} & $\begin{array}{l}\text { Convention on } \\
\text { the Physical } \\
\text { Protection of } \\
\text { Nuclear Material } \\
\text { (CPPNM) } \\
\text { INFCIRC/225 }\end{array}$ & IAEA & $\begin{array}{l}\text { Serves as } \\
\text { depositary of } \\
\text { CPPNM } \\
\text { Provides } \\
\text { guidance, } \\
\text { training, } \\
\text { assessment }\end{array}$ & \multirow{3}{*}{$\begin{array}{l}\text { Physical } \\
\text { Protection of } \\
\text { Plants and } \\
\text { Materials, } 10 \\
\text { CFR part } 73 \\
\\
\text { Physical } \\
\text { Protection, DOE } \\
\text { Manual M } \\
\text { 470.4-2 Chg } 1\end{array}$} & \multirow[t]{3}{*}{ NRC } & \multirow{3}{*}{ 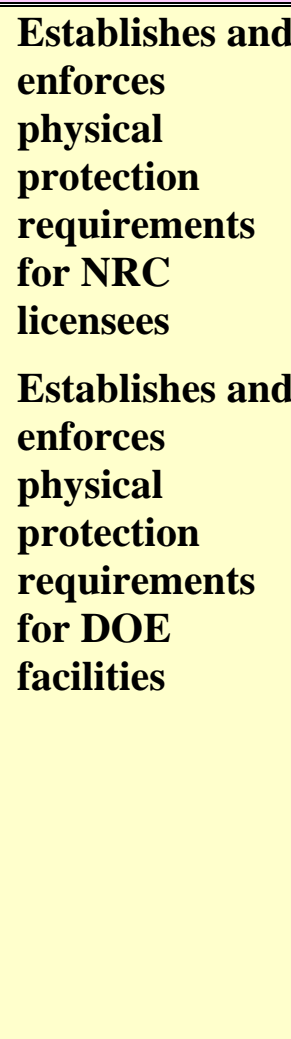 } \\
\hline & $\begin{array}{l}\text { International } \\
\text { Convention for } \\
\text { the Suppression } \\
\text { of Acts of } \\
\text { Nuclear } \\
\text { Terrorism } \\
\text { (Nuclear } \\
\text { Terrorism } \\
\text { Convention, } \\
\text { NTC) }\end{array}$ & IAEA & $\begin{array}{l}\text { Recommends } \\
\text { appropriate } \\
\text { measures }\end{array}$ & & & \\
\hline & UNSCR 1540 & 1540 Committee & $\begin{array}{l}\text { Promotes } \\
\text { implementation } \\
\text { of UNSCR } 1540\end{array}$ & & & \\
\hline $\begin{array}{l}\text { Nuclear-related } \\
\text { dual use items }\end{array}$ & N/A & N/A & N/A & N/A & N/A & N/A \\
\hline
\end{tabular}




\begin{tabular}{|c|c|c|c|c|c|c|}
\hline \multirow[t]{2}{*}{$\begin{array}{l}\text { Radioactive } \\
\text { Sources }\end{array}$} & $\begin{array}{l}\text { IAEA Code of } \\
\text { Conduct on the } \\
\text { Safety and } \\
\text { Security of } \\
\text { Radioactive } \\
\text { Sources }\end{array}$ & IAEA & $\begin{array}{l}\text { Develops } \\
\text { guidance, } \\
\text { facilitates } \\
\text { information } \\
\text { exchange, } \\
\text { receives States' } \\
\text { political } \\
\text { commitment to } \\
\text { implement }\end{array}$ & \multirow[t]{2}{*}{$\begin{array}{l}\text { Order Imposing } \\
\text { Increased } \\
\text { Controls, } \\
\text { December 1, } \\
2005 \\
\text { Other orders to } \\
\text { licensees }\end{array}$} & \multirow[t]{2}{*}{ NRC } & \multirow[t]{2}{*}{ 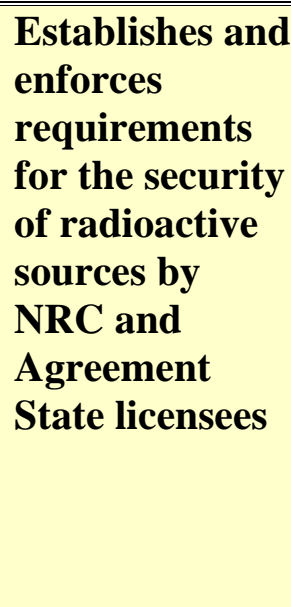 } \\
\hline & UNSCR 1540 & $\begin{array}{l}1540 \\
\text { Committee }\end{array}$ & $\begin{array}{l}\text { Promotes } \\
\text { implementation } \\
\text { of UNSCR } 1540\end{array}$ & & & \\
\hline
\end{tabular}




\section{PNWCGS Mission}

Our mission is to address the full range of global security issues by probing the impact of economic, social, institutional and environmental conditions that affect regional stability and global security. We emphasize non-proliferation due to its consequence for global security.

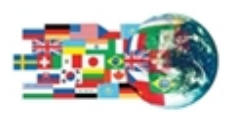

Pacific Northwest Center for

Global Security

For more information, contact:

Carol Kessler, Director

Pacific Northwest Center for Global Security

Pacific Northwest National Laboratory

1100 Dexter Avenue North, Suite 400

Seattle, WA 98109

Phone: 206-528-3222

Fax: 206-528-3225 